\title{
A study on groundwater geochemistry and water quality in layered aquifers system of Pondicherry region, southeast India
}

\author{
R. Thilagavathi $\cdot$ S. Chidambaram $\cdot$ \\ M. V. Prasanna $\cdot$ C. Thivya $\cdot$ C. Singaraja
}

Received: 28 January 2012/ Accepted: 22 April 2012/Published online: 24 May 2012

(C) The Author(s) 2012. This article is published with open access at Springerlink.com

\begin{abstract}
Geochemical signatures of groundwater in the Pondicherry region, south India, were determined. The coastal aquifers are fragile and this situation becomes more intense in layered aquifer systems like that of the Pondicherry region. In this region, groundwater occurs in alluvium, Lower Cuddalore, Upper Cuddalore, Tertiary, Cretaceous and mixed aquifers. The geochemical signature of groundwater in these formations was studied by collecting 93 groundwater samples. The collected samples from specific formations were analysed for physical parameters, such as electrical conductivity (EC), $\mathrm{pH}$ and major ion concentrations, such as $\mathrm{Ca}, \mathrm{Mg}, \mathrm{Na}, \mathrm{K}, \mathrm{Cl}$, $\mathrm{HCO}_{3}, \mathrm{PO}_{4}$ and $\mathrm{SO}_{4}$. The results of the analysis were interpreted with geology; the ionic concentrations in the groundwater vary spatially and temporally. The abundance of these ions are in the following order: $\mathrm{Na}>\mathrm{Ca}>$ $\mathrm{Mg}>\mathrm{K}=\mathrm{Cl}>\mathrm{HCO}_{3}>\mathrm{SO}_{4}$. Interpretation of analytical data shows that $\mathrm{Ca}-\mathrm{Na}$ and $\mathrm{Cl}-\mathrm{SO}_{4}-\mathrm{HCO}_{3}$ is the dominant facies in all the formations. Groundwater in the area is generally hard and fresh-brackish in most of the formations and brackish in nature in alluvium formation. The sodium absorption ratio shows that most of the samples are grouped under excellent category to good category in all the formations. The residual sodium carbonate also are in good category in all the formations. Chloro-alkaline indices reveal that the majority of samples show negative values in
\end{abstract}

R. Thilagavathi $\cdot$ S. Chidambaram $\cdot$ C. Thivya $\cdot$ C. Singaraja Department of Earth Sciences, Annamalai University, Annamalai Nagar, Chidambaram 608002, India

M. V. Prasanna ( $\square)$

Department of Applied Geology, School of Engineering and Science, Curtin University, Sarawak Campus, CDT 250, 98009 Miri, Sarawak, Malaysia

e-mail: geoprasanna@gmail.com all the litho units indicating the exchange of $\mathrm{Na}$ and $\mathrm{K}$ in groundwater with $\mathrm{Mg}$ or $\mathrm{Ca}$ in rock. Scholler classification of water indicates that longer residence time of water with more prominent base exchange. High EC and TDS values in certain locations of alluvial, Upper Cuddalore and Cretaceous formations prove to be unsuitable for drinking and irrigation purposes.

Keywords Groundwater - Aquifers · Geochemistry · Water quality $\cdot$ Pondicherry

\section{Introduction}

The emerging global freshwater crisis in terms of water quality and quantity is already felt in India. The overdrafting of groundwater in India due to the lack of surface waters during summer season has urged the need to undertake a detailed study on the quality and quantity of groundwater in different parts of India. Water quality gets modified along the course of movement of water through the hydrological cycle and through the operation of the following processes: evaporation, transpiration, selective uptake by vegetation, oxidation/reduction, cation exchange, dissociation of minerals, precipitation of secondary minerals, mixing of waters, leaching of fertilizers and manure, pollution and biological processes (Appelo and Postma 1999). The quality of water is of vital concern for mankind, since it is directly linked with human welfare. Poor quality of water adversely affects the plant growth and human health (Wilcox 1984; Thorne and Peterson 1954; US Salinity Laboratory Staff 1954; Holden 1971; Todd 1980; ISI 1983; WHO 1984; Hem 1991; Karanth 1997). Groundwater quality data give important clues to the geologic history of rocks and indications of 


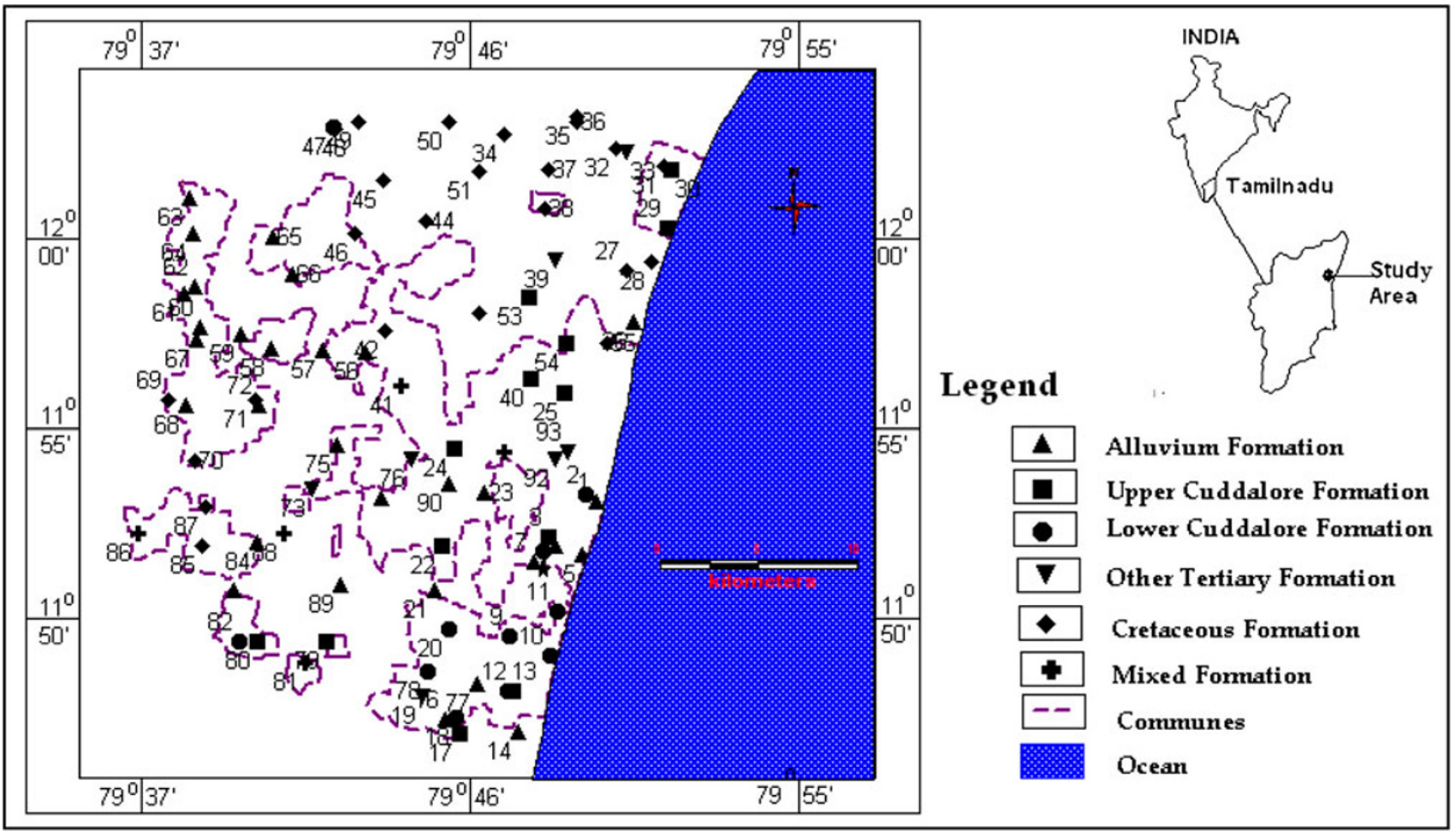

Fig. 1 Location map of the study area along with the water sampling points

groundwater recharge, movement and storage (Walton 1970). The knowledge of hydrochemistry is essential to determine the origin of chemical composition of groundwater (Zaporozec 1972). The hydrology and geochemistry of waters have been further discussed in the classic works of Stumm and Morgan (1996), Hem (1991), Drever (1988) and Domenico and Schwartz (1998). Determination of physical, chemical and bacteriological quality of water is essential for assessing its suitability for various purposes like drinking, domestic, agricultural and industrial uses. A number of studies on groundwater quality with respect to drinking and irrigation purposes have been carried out in different parts of India (Durvey et al. 1997; Agarwal and Jagetia 1997; Niranjan Babu et al. 1997; Subba Rao et al. 1999; Majumdar and Gupta 2000; Dasgupta and Purohit 2001; Khurshid et al. 2002; Sujatha and Reddy 2003; Pulle et al. 2005; Hussain et al. 2005; Sunitha et al. 2005; Subba Rao 2006). The study area is predominantly an agricultural zone with dense agricultural activities and also located near the coastal region. The majority of the people in this region depend on agriculture (i.e. cultivators and agricultural labourers). Both for drinking and irrigation purposes, substantial amount of groundwater is used in this area. Hence, this study forms the baseline attempt on the geochemistry of sub-surface water, impact of salt water intrusion and suitability for drinking and agricultural purposes in the study area.

\section{Physiography and geomorphology of the study area}

Pondicherry region is located on the east coast of India, forming enclaves within the Cuddalore District of Tamilnadu. It is surrounded by northern latitudes $11^{\circ} 45^{\prime}-12^{\circ} 03^{\prime}$ and eastern longitudes $79^{\circ} 37^{\prime}-79^{\circ} 53^{\prime}$ (Fig. 1). The region is bounded on the east by the Bay of Bengal and on the remaining sides by Cuddalore District. The Pondicherry region is a flat peneplain with an average elevation of about $15 \mathrm{~m}$ above MSL. The terrain becomes a little undulating with prominent high grounds varying from 30 to $45 \mathrm{~m}$ above mean sea level (MSL) towards interior northwest and northeastern parts of the region. Three major physiographic units are generally observed, namely (1) coastal plain, (2) alluvial plain and (3) uplands. There are two major rivers draining the Pondicherry region, namely the Gingee River in the north and Ponnaiyar River in the south. The Gingee River runs for $34 \mathrm{~km}$ in the region before joining the Bay of Bengal. The mean monthly temperature ranges between 22 and $33{ }^{\circ} \mathrm{C}$. The average annual rainfall at Pondicherry is 1,254.4 $\mathrm{mm}$ (CGWB 1993).

\section{Geology of the study area}

The entire area is covered by sedimentary formations ranging in age from Cretaceous to recent (Fig. 2a, b). The geological succession of the region is given in Table 1 . 
Fig. 2 a Geology map of the study area (after Pethaperumal 2010). b Cross section along the line $\mathrm{AB}$ in a (after Pethaperumal 2010) a
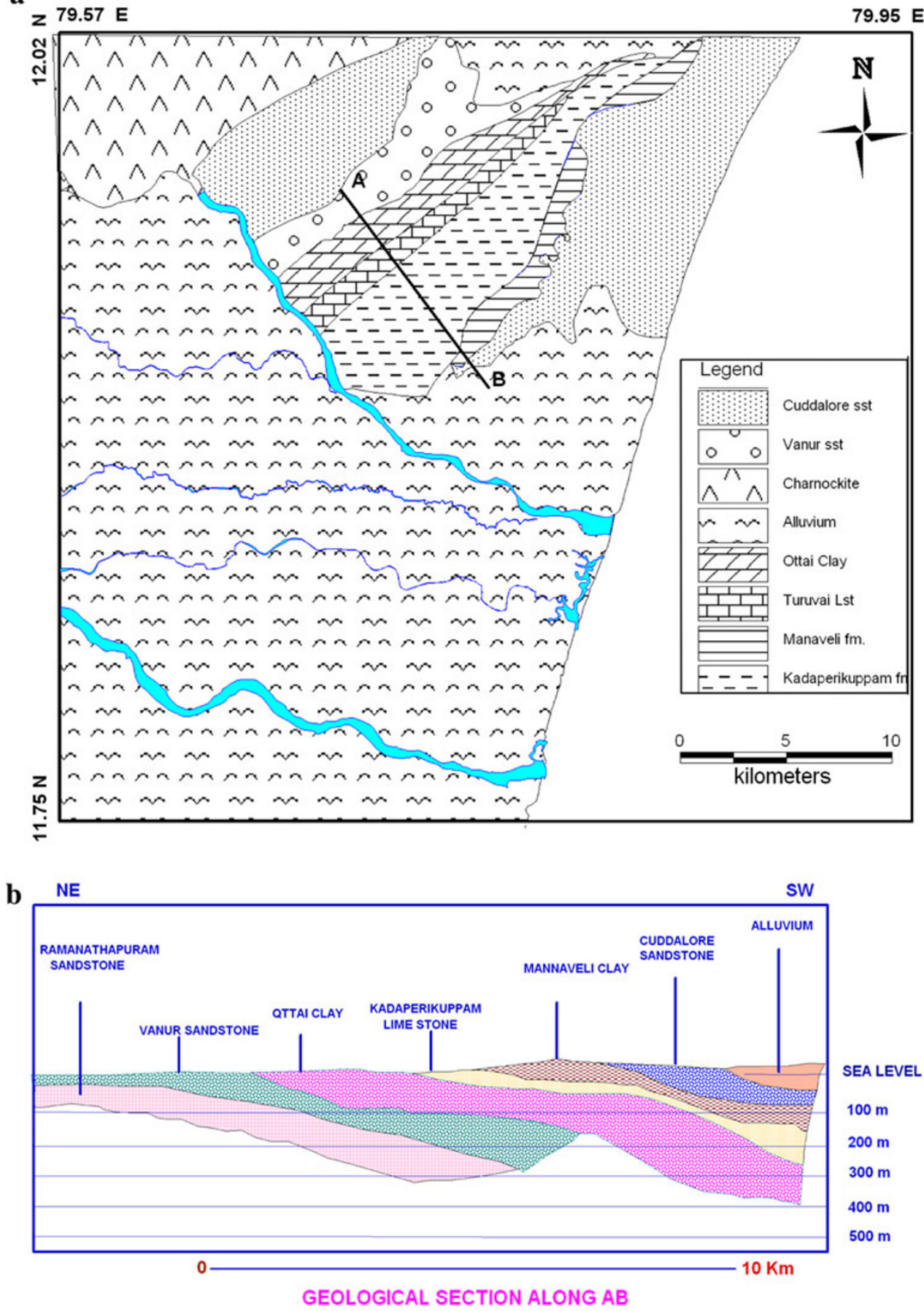

Cretaceous aquifers

\section{a) Ramanathapuram and Vanur aquifers}

They occur in the northwestern part of the Pondicherry region and are encountered in boreholes drilled in the major part of the region. The aquifers of this formation include sands and calcareous sandstones. They are coarse grained in the western part and graded into finer facies towards east and northeast. The thickness of these aquifers ranges between 38 and $92 \mathrm{~m}$.
Groundwater occurs under confined conditions, and the piezometric head at present is about 20 to $60 \mathrm{mbgl}$. The depth of the tube wells tapping these aquifers ranges between $65 \mathrm{~m}$ in the NW and $300 \mathrm{~m}$ in the NE of Pondicherry region. The yield of the tube wells tapping these aquifers ranges between 120 and $700 \mathrm{lpm}$. The investigation carried out reveals that the transmissivity value of these aquifers ranges between 92 and $1,925 \mathrm{~m}^{2} /$ day. The storage coefficient value ranges between $2.93 \times 10^{-5}$ and $1.36 \times 10^{-4}$. 
Table 1 Geological succession of the study area (CGWB 1993)

\begin{tabular}{|c|c|c|c|}
\hline Era & Period & Formation & Lithology \\
\hline Quarternary & Recent & Alluvium & Sands, clays, silts, kankar, and gravels \\
\hline Tertiary & $\begin{array}{l}\text { Mio- } \\
\text { Pliocene }\end{array}$ & Cuddalore & $\begin{array}{l}\text { Sandstone, pebbly and gravelly and coarse grained with } \\
\text { minor clays and silt stones and thin seams of lignite }\end{array}$ \\
\hline \multicolumn{4}{|c|}{ Unconformity } \\
\hline Tertiary & Palaeocene & Manaveli & $\begin{array}{l}\text { Yellow and yellowish brown, gray calcareous siltstone } \\
\text { and claystone, and shale with thin bands of limestone }\end{array}$ \\
\hline Tertiary & Palaeocene & Kadapepperikuppam & $\begin{array}{l}\text { Yellowish white to dirty white, sandy, hard fossiliferous } \\
\text { limestone, calcareous sandstone and clay }\end{array}$ \\
\hline \multicolumn{4}{|c|}{ Unconformity } \\
\hline Mesozoic & $\begin{array}{l}\text { Upper } \\
\text { Cretaceous }\end{array}$ & Turuvai limestone & $\begin{array}{l}\text { Highly fossiliferous limestone, conglomeritic at places, } \\
\text { calcareous sandstone, and clays }\end{array}$ \\
\hline Mesozoic & $\begin{array}{l}\text { Upper } \\
\text { Cretaceous }\end{array}$ & Ottai claystone & $\begin{array}{l}\text { Greyish to greyish green claystones, siltstone with thin } \\
\text { bands of sandy limestone and fine-grained calcareous } \\
\text { sandstone. }\end{array}$ \\
\hline Mesozoic & $\begin{array}{l}\text { Upper } \\
\text { Cretaceous }\end{array}$ & Vanur sandstone & $\begin{array}{l}\text { Quartzose sandstone, hard coarse grained, occasionally } \\
\text { felspathic or calcareous with minor clays }\end{array}$ \\
\hline Mesozoic & $\begin{array}{l}\text { Lower } \\
\text { Cretaceous }\end{array}$ & $\begin{array}{l}\text { Ramanathapuram } \\
\text { (unexposed) }\end{array}$ & $\begin{array}{l}\text { Black carbonaceous, silty clays and fine- to medium- } \\
\text { grained sands with bands of lignite and sandstone, } \\
\text { medium to coarse grained }\end{array}$ \\
\hline \multicolumn{4}{|c|}{ Unconformity } \\
\hline Archaeans & & $\begin{array}{l}\text { Eastern Ghats } \\
\text { complex }\end{array}$ & Charnockite and biotite hornblende gneisses \\
\hline
\end{tabular}

\section{b) Ottai aquifers}

The Upper Cretaceous Ottai Formations are constituted mainly by clay stone. The water-bearing property of Ottai aquifers is chiefly dependent on the few bands of finegrained sandstone and limestone occurring locally at deeper depths and, as a result, yields meagre to moderate quantity of water. The thickness of this aquifer varies from 42 to $56 \mathrm{~m}$ and the yield of the wells ranges between 120 and $600 \mathrm{lpm}$ with drawdown varying from 6.6 to $25 \mathrm{~m}$.

Tertiary aquifers

a) The Manaveli Formation of Palaeocene is mainly an aquitard and the localized granular zones do not provide any appreciable yield. Another unit of this group, namely the Kadapperikuppam Formation, contains some productive aquifers. The thickness of this aquifer shows wide lateral and vertical variations. Amongst Tertiary aquifers, the Cuddalore sandstones of MioPliocene age constitute the most potential aquifers.

b) Kadapperikkuppam Aquifers

The aquifers of this group are constituted by fine-grained sandstones and give moderate to good yield as seen around Sedarapet, Pillaiyarkuppam and further northeast. The thickness of aquifer ranges between 52 and $90 \mathrm{~m}$ in the areas south of Gingee River, whereas in the areas the north of Gingee River, it is between 13 and $37 \mathrm{~m}$. Groundwater occurs under un-confined condition. The investigation carried out reveals a field permeability of $3 \mathrm{~m} /$ day in the areas to the south of Gingee River, whereas towards north of Gingee River it is around $0.8 \mathrm{~m} /$ day.

c) Cuddalore sandstone aquifers

The Cuddalore Sandstones (Upper Tertiary), comprising sandstones and gravels, occupy an extensive area in the region. The thickness of this aquifer in Ozhukarai that communes with the north of Gingee River ranges between 20 and $66 \mathrm{~m}$, and the maximum thickness of $245 \mathrm{~m}$ is encountered in Bahour commune in the southern part of the region. The yield of the tube wells tapping this aquifer ranges between 200 and 3,000 lpm with drawdown varying from 5 to $10 \mathrm{~m}$. The piezometric level in this aquifer ranges between 10 and $25 \mathrm{~m}$ bgl. The investigation carried out reveals that the average transmissivity values of these aquifers are around $2,000 \mathrm{~m}^{2} /$ day. The storage coefficient value ranges between $9.583 \times 10^{-5}$ and $8.9 \times 10^{-4}$.

Alluvial aquifer

Sands and gravels constitute the alluvial aquifer. Alluvial deposits occupy nearly three-fourths of the study area. These aquifers form the most potential shallow aquifer system of the study area, with thickness ranging between 5 and $34 \mathrm{~m}$. Thick alluvial aquifers occur in the area bordered by Thirukanji, Odiyampet, Thavalakuppam, Villianur, Mangalam and Sathamangalam. Groundwater occurs 
in this aquifer under un-confined to semi-confined condition. The depth of the tube wells tapping this aquifer ranges between 25 and $50 \mathrm{~m}$ bgl. The average annual fluctuation is around $7.50 \mathrm{~m}$. The studies (CGWB 1993) indicate that the transmissivity values of the aquifers in the west are $275.4 \mathrm{~m}^{2} /$ day at Madukarai and $770 \mathrm{~m}^{2} /$ day at Thirukanji in the east.

\section{Hydrogeology}

As mentioned earlier, the sedimentary formations occur in almost the entire region and are represented by Cretaceous, Palaeocene, Mio-Pliocene and Quaternary formations. Groundwater occurs in these formations both under water table as well as under confined conditions and is developed by means of dug wells, dug cum borewells and tube wells.

\section{Methodology}

From borewells, 93 groundwater samples were collected in order to cover different litho units in the study area [alluvium (31), Tertiary (Upper Cuddalore sandstone) (15), Tertiary (Lower Cuddalore sandstone) (15), Other Tertiary (7), Cretaceous (25) and mixed (5)] (Fig. 1). The samples were analysed using standard procedures (APHA 1998). Major cations such as $\mathrm{Ca}$ and $\mathrm{Mg}$ were analysed by titrimetry, $\mathrm{Na}$ and $\mathrm{K}$ by flame photometer (Elico CL 378), major anions $\mathrm{Cl}$ and $\mathrm{HCO}_{3}$ by titrimetry, and $\mathrm{SO}_{4}, \mathrm{PO}_{4}$ and $\mathrm{H}_{4} \mathrm{SiO}_{4}$ by spectrophotometer (SL 171 minispec). EC and $\mathrm{pH}$ were determined in the field itself using electrode (Thermo). The total cation $\left(\mathrm{Tz}^{+}\right)$and total anion $\left(\mathrm{Tz}^{-}\right)$ balance (Domenico and Schwartz 1998; Freeze and Cherry, 1979) is considered to show the ionic balance error percentage. The error percentage in the samples ranged from \pm 1 to $\pm 10 \%$.

\section{Results and discussion}

Maximum and minimum values for the chemical composition of groundwater is given in Table 2, compared with WHO standards. The abundance of ions is in the following order: $\mathrm{Na}>\mathrm{Ca}>\mathrm{Mg}>\mathrm{K}=\mathrm{Cl}>\mathrm{HCO}_{3}>\mathrm{SO}_{4}$.

\section{Hydrochemical facies}

Piper diagrams (Piper 1953) are drawn by plotting the proportions (in equivalents) of the major cations $\left(\mathrm{Ca}^{2+}\right.$, $\left.\mathrm{Mg}^{2+}, \mathrm{Na}^{+}+\mathrm{K}^{+}\right)$on one triangular diagram, the proportions of the major anions $\left(\mathrm{CO}_{3}^{-}+\mathrm{HCO}_{3}^{-}, \mathrm{Cl}^{-}, \mathrm{SO}_{4}{ }^{2-}\right)$ on another, and combining the information from the two triangles on a quadrilateral. The position of this plotting indicates the relative composition of groundwater in terms of the cation-anion pairs that correspond to four vertices of the field. The geochemical evolution can be understood from the Piper plot (Fig. 3), which has been divided into six sub-fields, viz. 1 ( $\mathrm{Ca}-\mathrm{HCO}_{3}$ type); 2 ( $\mathrm{Na}-\mathrm{Cl}$ type); 3 (mixed $\mathrm{Ca}-\mathrm{Na}-\mathrm{HCO}_{3}$ type); 4 (mixed $\mathrm{Ca}-\mathrm{Mg}-\mathrm{Cl}$ type); 5 ( $\mathrm{Ca}-\mathrm{Cl}$ type) and $6\left(\mathrm{Na}-\mathrm{HCO}_{3}\right.$ type). The groundwater samples were collected from different formations like, Cretaceous, Tertiary and alluvium. Hence, it is presumed that the samples reveal the characters of the same term 'hydrosome' which is analogous to the stratigraphic concept 'lithosome' (Krumbein and Sloss 1963). Within a given hydrosome, the

Table 2 Maximum and minimum values of the chemical composition of groundwater samples

\begin{tabular}{|c|c|c|c|c|c|c|c|}
\hline \multirow[t]{2}{*}{ Parameters } & \multirow{2}{*}{$\begin{array}{l}\text { Alluvium } \\
(n=31)\end{array}$} & \multicolumn{3}{|l|}{ Tertiary } & \multirow{2}{*}{$\begin{array}{l}\text { Cretaceous } \\
(n=25)\end{array}$} & \multirow{2}{*}{$\begin{array}{l}\text { Mixed } \\
(n=5)\end{array}$} & \multirow{2}{*}{$\begin{array}{l}\text { WHO } \\
2004\end{array}$} \\
\hline & & $\begin{array}{l}\text { Lower Cuddalore } \\
(n=13)\end{array}$ & $\begin{array}{l}\text { Upper Cuddalore } \\
(n=13)\end{array}$ & $\begin{array}{l}\text { Other Tertiary } \\
(n=7)\end{array}$ & & & \\
\hline $\mathrm{EC}$ & $334-3,310(19)$ & $321-3,250(1)$ & $270-1,432$ (2) & $562-1,571(1)$ & $340-3,127$ (7) & $810-2,795(1)$ & 1,400 \\
\hline $\mathrm{pH}$ & $6.6-7.8$ & $6.6-7.82$ & $6.22-7.65$ & $6.77-7.71$ & $6.24-7.84$ & $7.02-7.65$ & $6.5-8.5$ \\
\hline TDS & $241-2,250(18)$ & $205-2,190(3)$ & 211-993 & $444-1,054$ (1) & $234-2,376$ (4) & $518-1,905$ (3) & $500-1,000$ \\
\hline $\mathrm{Ca}$ & $12-104(1)$ & $28-88$ & $16-112(1)$ & $32-72$ & $20-172(3)$ & $28-64$ & 100 \\
\hline $\mathrm{Mg}$ & $7.2-62.4(1)$ & $0-33$ & $7.2-48$ & $12-28.8$ & $2.4-45$ & $14-26$ & 50 \\
\hline $\mathrm{Na}$ & $20-517$ (12) & $7-567(1)$ & $12-146$ & 27-389 (1) & $6.8-550(3)$ & $67-176$ & 200 \\
\hline $\mathrm{K}$ & $0.1-47(2)$ & $0-18$ & $0-8$ & $0.2-4.8$ & $0.1-16.9$ & $0-11$ & 20 \\
\hline $\mathrm{HCO}_{3}$ & $73.2-1,475.8$ (4) & $73-402.6(1)$ & $85.4-268.4$ & $109-305$ & $73-366$ & $170-268$ & $125-350$ \\
\hline $\mathrm{SO}_{4}$ & $0-28$ & $0-11$ & $0-4$ & $0.04-9.2$ & $0.4-44$ & $2.4-13.6$ & 250 \\
\hline $\mathrm{Cl}$ & $35-797(23)$ & 53-744 (3) & $26-389$ (2) & $70-602(2)$ & 53-904 (7) & $88-390(2)$ & 250 \\
\hline
\end{tabular}

All the values are in $\mathrm{mg} / \mathrm{L}$ except $\mathrm{pH}$ and $\mathrm{EC}$ in $\mu \mathrm{s} / \mathrm{cm}$; numbers within the bracket represent the number of samples beyond the WHO limit 
Fig. 3 Piper facies diagram for groundwater samples

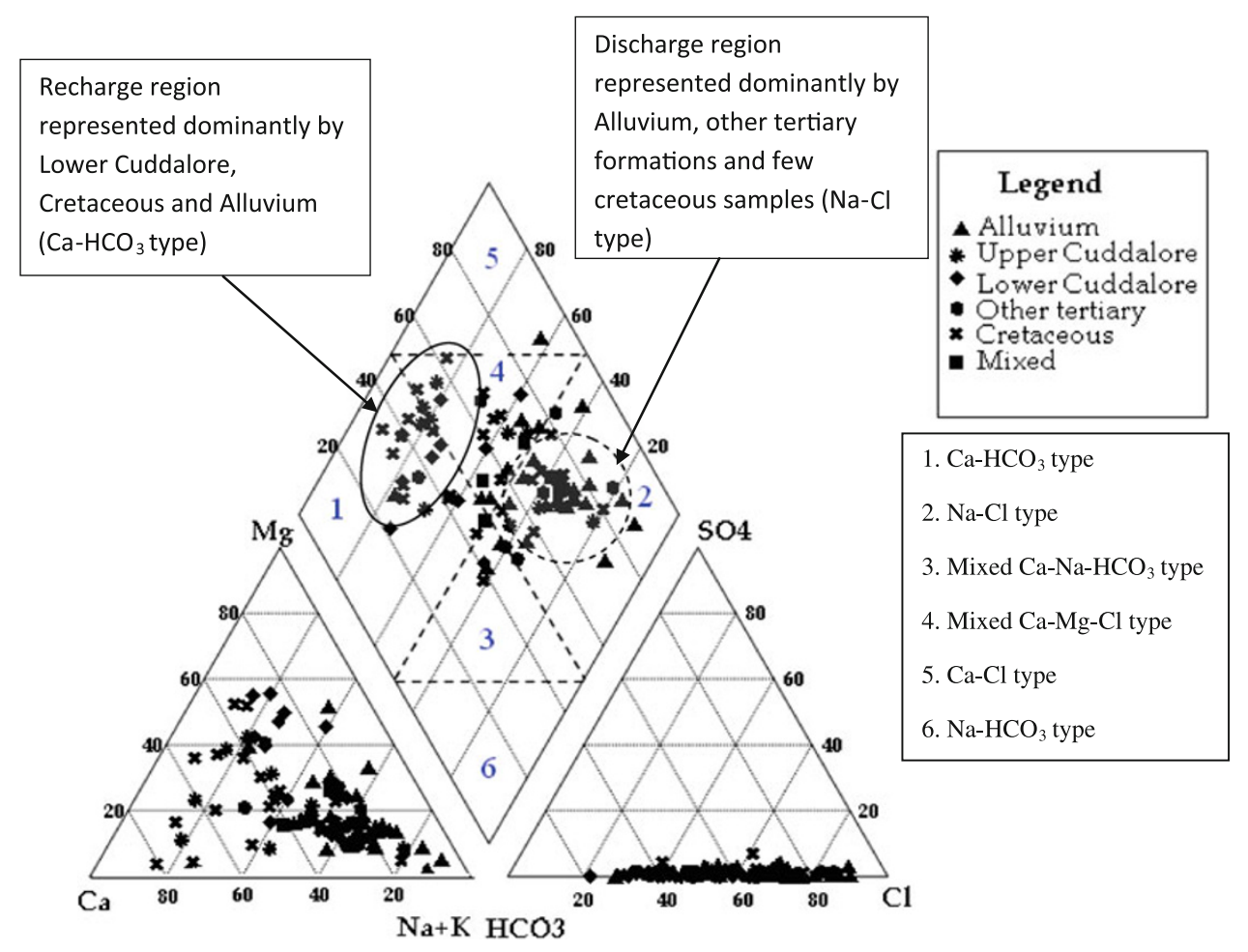

chemical composition of water varies in time and space due to changes in recharge composition and flow patterns, and due to chemical processes between the water and the porous medium. Such variations in chemical character are used to subdivide a hydrosome into characteristic zones, or 'hydrochemical facies', a term introduced by Back (1960).

In alluvium formation, samples are clustered in the fields of 2, 3 and 4, and the majority of the samples are concentrated in the $\mathrm{Na}-\mathrm{Cl}$ type (Fig. 3), indicating the saline nature in the groundwater (Prasanna et al. 2010). Strong quality fluctuations are induced mainly by cyclic atmospheric and biological changes, to a very stable water quality and by longitudinal and transversal dispersion (Stuyfzand 1993). Equilibrium between the exchange complex of the porous medium and its interstitial water to ion exchange and site reactions was noted during and after displacement by another hydrosome (Versluys 1931; Stuyfzand 1992). A similar process happens when fresh dune water intrudes into a coastal aquifer containing salt water. In Tertiary and Lower Cuddalore Formation, the dominant fields are 1, 2 and 4, and the majority of the samples are concentrated in $\mathrm{Ca}-\mathrm{HCO}_{3}$ facies indicating the dominance of freshwater recharge into the aquifers. In Upper Cuddalore Formation, samples mainly fall in the fields of 1,2 and 4. The same trend was followed in the Cretaceous formation (Fig. 2), and most of the samples fall in the $\mathrm{Ca}-\mathrm{HCO}_{3}$ facies indicating the dominance of freshwater recharge. In mixed aquifer, the samples are of $\mathrm{Ca}-\mathrm{HCO}_{3}$ and $\mathrm{Na}-\mathrm{Cl}$ types. Stuyfzand (1999) points out that fresh to brackish or saline water occurs by hydrodynamic dispersion across the boundaries of adjacent hydrosomes or by continued evapotranspiration. The latter may lead to evolution lines described by Hardie and Eugster (1978) and Jankowski and Jacobson (1989).

Shipovalov (1984) recognizes three types of hydrochemical zones on a global scale: (1) horizontal or latitudinal zonation (2) vertical zonation and (3) altitudinal zonation. The study area is dominantly coastal alluvium with lesser variation in the topography; more over, the samples are collected with respect to formations. Hence, the horizontal zonation of geochemical facies with respect to formation will provide us the information about the variation in the geochemistry along its flow path. In general, a gradual increase of the mineralization of groundwater and shift from the dominant anion $\mathrm{HCO}_{3}$ via $\mathrm{SO}_{4}$ to $\mathrm{Cl}$ are observed in waters moving from shallow to greater depth, due to decreasing groundwater circulation and increasing water-rock interaction. The decreasing flushing rate of the aquifer system with meteoric water probably is the most dominant factor, because of its major impact on each of Shipovalov's zones.

Hydrogeochemical process evaluation

A hydrochemical diagram proposed by (Chadha 1999) has been applied in this study to interpret the hydrochemical processes occurring in the study area. The same procedure was successfully applied by (Karmegam et al. 2010; 
Fig. 4 Chadda's geochemical process evolution plot

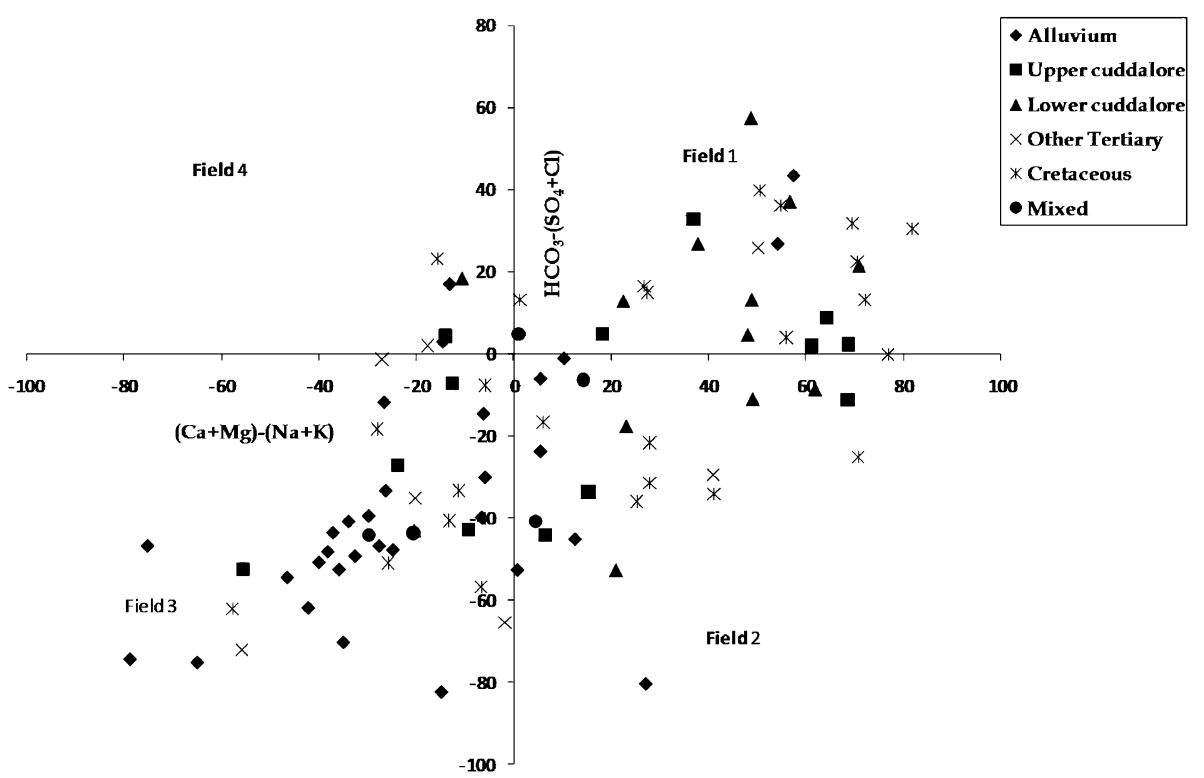

Vandenbohede et al. 2010) in a coastal aquifer to determine the evolution of two different hydrogeochemical processes. Data were converted to percentage reaction values (milliequivalent percentages) and expressed as the difference between alkaline earths $(\mathrm{Ca}+\mathrm{Mg})$ and alkali metals $(\mathrm{Na}+\mathrm{K})$ for cations, and the difference between weak acidic anions $\left(\mathrm{HCO}_{3}+\mathrm{CO}_{3}\right)$ and strong acidic anions $\left(\mathrm{Cl}+\mathrm{SO}_{4}\right)$. The hydrochemical processes suggested by Chadha (1999) are indicated in each of the four quadrants of the graph. These are broadly summarized as:

Field 1: $\mathrm{Ca}-\mathrm{HCO}_{3}$ type of recharging waters

Field 2: $\mathrm{Ca}-\mathrm{Mg}-\mathrm{Cl}$ type of reverse ion-exchange waters

Field 3: $\mathrm{Na}-\mathrm{Cl}$ type of end-member waters (seawater)

Field 4: $\mathrm{Na}-\mathrm{HCO}_{3}$ type of base ion-exchange waters

The resultant diagram is shown in Fig. 4 and the majority of alluvium samples fall in Field $3(\mathrm{Na}-\mathrm{Cl})$ suggesting that the waters show typical seawater mixing and are mostly constrained to the coastal areas. Most of the
Upper and Lower Cuddalore and Cretaceous samples are in Field 1 (recharging water). When water enters into the ground from the surface, it carries dissolved carbonate in the form of $\mathrm{HCO}_{3}$ and the geochemically mobile Ca. Few samples in all the formations fall in Field 2 (reverse ion exchange), revealing that the waters are less easily defined and less common, but represent groundwater where $\mathrm{Ca}+\mathrm{Mg}$ is in excess to $\mathrm{Na}+\mathrm{K}$ either due to the preferential release of $\mathrm{Ca}$ and $\mathrm{Mg}$ from mineral weathering of exposed bedrock or possibly reverse base cation-exchange reactions of $\mathrm{Ca}+\mathrm{Mg}$ into solution and subsequent adsorption of $\mathrm{Na}$ into mineral surfaces (Karmegam et al. 2010). Field $4\left(\mathrm{Na}-\mathrm{HCO}_{3}\right)$ waters, which is less prominent in the study area.

Seawater has distinct ionic ratios, as presented in Table 3 (Vengosh et al. 2002; Vengosh and Rosenthal 1994). Relatively, $29 \%$ of alluvium and Other Tertiary samples show the high $\mathrm{Na}^{+} / \mathrm{Cl}^{-}$and $\mathrm{Ca}^{2+} /$ $\left(\mathrm{HCO}_{3}{ }^{-}+\mathrm{SO}_{4}{ }^{2-}\right.$ ) ratios (greater than unity) (Vengosh

Table 3 Comparative ionic ratio of potential salinization sources with present groundwater compositions

\begin{tabular}{|c|c|c|c|c|c|c|c|}
\hline Parameter & $\begin{array}{l}\text { Seawater } \\
\text { intrusion }\end{array}$ & $\begin{array}{l}\text { Alluvium } \\
(n=31)(\%)\end{array}$ & $\begin{array}{l}\text { Tertiary Upper } \\
\text { Cuddalore } \\
(n=13)(\%)\end{array}$ & $\begin{array}{l}\text { Tertiary Lower } \\
\text { Cuddalore } \\
(n=13)(\%)\end{array}$ & $\begin{array}{l}\text { Other Tertiary } \\
(n=7)(\%)\end{array}$ & $\begin{array}{l}\text { Cretaceous } \\
(n=25)(\%)\end{array}$ & $\begin{array}{l}\text { Mixed } \\
(n=5)(\%)\end{array}$ \\
\hline $\mathrm{Na}^{+} / \mathrm{Cl}^{-}$ & $0.86-1^{\mathrm{a}}$ & 29 & 7.6 & 7.6 & 28.5 & 20 & 20 \\
\hline $\mathrm{SO}_{4}{ }^{2-} / \mathrm{Cl}^{-}$ & $0.05^{\mathrm{a}, \mathrm{c}}$ & - & - & - & - & 8 & - \\
\hline $\mathrm{K}^{+} / \mathrm{Cl}^{-}$ & 0.019 & - & - & - & - & - & - \\
\hline $\mathrm{Mg}^{2+/} \mathrm{Ca}^{2+}$ & $>5^{\mathrm{b}}$ & - & - & - & - & - & - \\
\hline $\mathrm{Ca}^{2+} /\left(\mathrm{HCO}_{3}{ }^{-}+\mathrm{SO}_{4}{ }^{2-}\right)$ & $0.35-1$ & 35.4 & 69.2 & 30.7 & 42.8 & 68 & 60 \\
\hline
\end{tabular}

\footnotetext{
a Vengosh and Rosenthal (1994)

b Vengosh and Ben-Zvi (1994)

c Vengosh et al. (1994)
} 
et al. 2002). Each probable source of salinization is characterized by a distinguishable chemistry and well-known ionic ratios. For example, if seawater intrusion is expected to be the only source of salinization, then the $\mathrm{Mg}^{2+} / \mathrm{Ca}^{2+}$ ionic ratio will be greater than 5 . The $\mathrm{Mg}^{2+} / \mathrm{Ca}^{2+}$ ionic ratio greater than 5 is a direct indicator of seawater contamination (Metcafe and Eddy 2000). Likewise, seawater and seawater diluted with freshwater have distinguished geochemical characteristics (Metcafe and Eddy 2000). The value of these ratios in the study area is greater than unity and may be due to deep saline upconing or ion-exchange process.

Modification of the geochemical characteristics of these saline waters is caused by water-rock interaction in which three possible mechanisms may be involved: (1) baseexchange reactions with clay minerals (Vengosh et al. 1994); (2) adsorption onto clay minerals; and (3) carbonate dissolution-precipitation (Vengosh et al. 1994; Ghabayen et al. 2006).

The improper treatment and disposal of domestic wastewater could be one of the major sources of salinization in the coastal aquifers (Metcafe and Eddy 2000). The chemical character of polluted water with urban wastewater or from the reuse of treated wastewater is very distinguishable. Sewage effluent has a relatively high $\mathrm{Na}^{+} / \mathrm{Cl}^{-}$ratio (greater than unity) and comparatively high $\mathrm{SO}_{4}{ }^{2-} / \mathrm{Cl}^{-}$ratio (0.09) (Ghabayen et al. 2006). These ratios are attributed to applications of $\mathrm{Na}-\mathrm{Cl}$ salts and domestic wastewater characteristics. Agriculture return flows have a distinctive chemical composition relative to other salinization sources. This water is characterized by high $\mathrm{SO}_{4}{ }^{2-} / \mathrm{Cl}^{-}$ratios, and $8 \%$ in Cretaceous shows much greater than 0.05 (Vengosh et al. 2002). A high $\mathrm{SO}_{4}{ }^{2-} / \mathrm{Cl}^{-}$ratio is attributed to the application of gypsum fertilizers (Vengosh et al. 2002). Lesser values of $\mathrm{K} / \mathrm{Cl}$ and $\mathrm{SO}_{4} / \mathrm{Cl}^{-}$are noted in the deeper aquifers, indicating relatively lesser anthropogenic impact.

The comparison of the $\mathrm{Na}^{+} / \mathrm{Cl}^{-}$ratio shows that freshwater mixing with seawater is responsible for high salinity in the area (Table 3). Migration of anthropogenic impact or dissolution and leaching of precipitated salts is also evident by the high $\mathrm{SO}_{4}{ }^{2-} / \mathrm{Cl}^{-}$ratio in Cretaceous aquifers, which substantiate that there is some impact from agriculture return flows. It is also true in the background that salt patches can be easily observed in the area at the time of high evapotranspiration. Nevertheless, this temporary phase has been released and once again inland salinity seems to be the governing factor. $\mathrm{K}^{+}$seems to be contributed from anthropogenic sources; this finding gets strengthened by the comparison of $\mathrm{K}^{+} / \mathrm{Cl}^{-}$ratio that was found to be quite higher and equivalent to wastewater infiltration. $\mathrm{Ca}^{2+} /\left(\mathrm{HCO}_{3}{ }^{-}+\right.$ $\mathrm{SO}_{4}{ }^{2-}$ ) ratio depicts that the seawater intrusion process is mostly responsible (Kumar et al. 2006).

Figure 5 shows the relationship of $\mathrm{pH}$ to $\left(\mathrm{Ca}^{2+}+\right.$ $\left.\mathrm{Mg}^{2+}\right) / \mathrm{HCO}_{3}{ }^{-}$ratio. $\mathrm{pH}$ determines the nature of carbonate

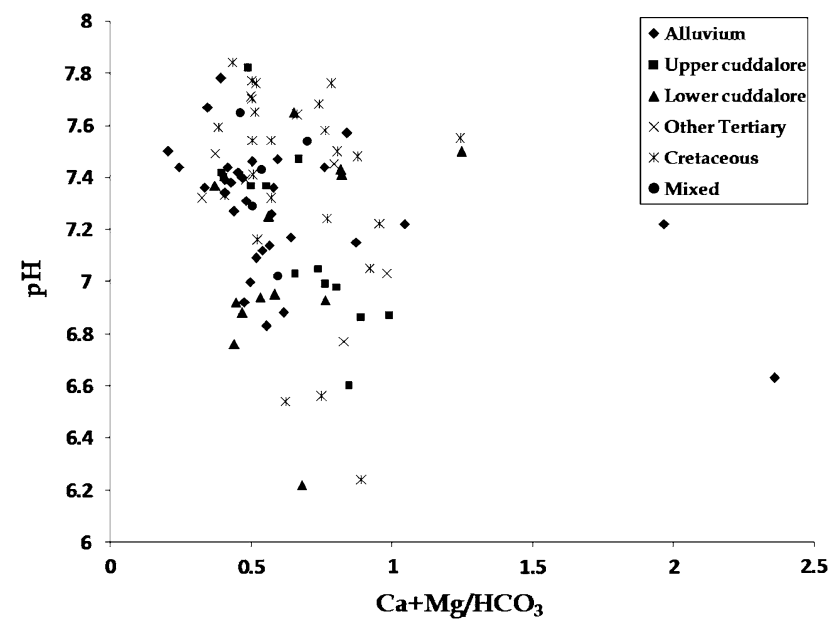

Fig. 5 Relationship of $(\mathrm{Ca}+\mathrm{Mg}) / \mathrm{HCO}_{3}$ ratio to $\mathrm{pH}$

present in water as $\mathrm{H}_{2} \mathrm{CO}_{3}{ }^{-}, \mathrm{HCO}_{3}{ }^{-}$, and $\mathrm{CO}_{3}{ }^{-}$, in acidic to alkaline $\mathrm{pH}$ conditions. The $\mathrm{pH}$ of the study area ranges from acidic to alkaline condition. The gradual increase of $\mathrm{pH}$ might be due to the higher amount of $\mathrm{H}^{+}$availability in all the aquifers. This may be due to nonavailability of neutralizing ions or strong ion-exchange complex by cation with clay minerals. This process also helps us to evaluate the $\mathrm{H}^{+}$ions circulation in the groundwater. Higher concentration of $\mathrm{H}^{+}$ions available in alluvial aquifers is neutralized by the process of weathering and dissolution. Further, in Lower Cuddalore, the $\mathrm{pH}$ decreases due to the exchange of cations in clay/rock matrix with $\mathrm{H}^{+}$ions in groundwater or the availability of neutralizing ions. The groundwater from the study area mostly show the $\left[\mathrm{Ca}^{2+}+\mathrm{Mg}^{2+}\right] /\left[\mathrm{HCO}_{3}{ }^{-}\right]$ratios below 1 in all the formations, and only few samples in alluvium show ratios above 1. Samples with lower ratios indicate additional $\mathrm{HCO}_{3}{ }^{-}$ input from albite mineral weathering, rather than from $\mathrm{Ca}^{2+}$ and $\mathrm{Mg}^{2+}$ production reactions alone.

The $\left(\mathrm{mCa}^{2+}+\mathrm{mMg}^{2+}-\mathrm{mSO}_{4}{ }^{2-}\right)$ versus $\left(\mathrm{mNa}^{+}+\right.$ $\left.\mathrm{mK}^{+}-\mathrm{mCI}^{-}\right)$relationship provides information on the geological sources of $\mathrm{Ca}^{2+}$ and $\mathrm{Mg}^{2+}$ in the aquifer. To account for meteoric $\mathrm{Ca}^{2+}$ from the dissolution of evaporate gypsum $\left(\mathrm{CaSO}_{4}{ }^{-}\right)$, an amount of $\mathrm{Ca}^{2+}$ equal to the concentration of $\mathrm{SO}_{4}{ }^{2-}$ is subtracted from the sum of $\mathrm{Ca}^{2+}$ and $\mathrm{Mg}^{2+}$ ions. Calculation of $\mathrm{Na}^{+}$values depletion caused by cation exchange was done by assuming that all meteoric $\mathrm{Na}^{+}$inputs are from $\mathrm{Na}^{+} \mathrm{Cl}^{-}$. Since all $\mathrm{Cl}^{-}$ions are meteoric in origin, subtracting $\mathrm{Cl}^{-}$from the total $\mathrm{Na}^{+}$ determines the meteoric $\mathrm{Na}^{+}$contribution. There are four fields demarcated in Fig. 6. It is to be noted that the ' $Y$ ' axis crosses the ' $X$ ' axis at 1 , i.e. the line along which $(\mathrm{Ca}+\mathrm{Mg})^{*} / \mathrm{HCO}_{3}$ is equal to unity. Field 1 has higher ratio of $(\mathrm{Na}+\mathrm{K}) * / \mathrm{HCO}_{3}$ and $(\mathrm{Ca}+\mathrm{Mg}) * / \mathrm{HCO}_{3}$, with $\mathrm{Na}^{+}+\mathrm{K}^{+}-\mathrm{Ca}^{2+}+\mathrm{Mg}^{2+}-\mathrm{HCO}_{3}{ }^{-}$water type. Field 2 shows the dominance of excess $\left(\mathrm{Ca}^{2+}+\mathrm{Mg}^{2+}\right)^{*}$ and higher 
Fig. 6 The ratio between the $(\mathrm{Ca}+\mathrm{Mg}) * / \mathrm{HCO}_{3}$ and

$(\mathrm{Na}+\mathrm{K})^{*} / \mathrm{HCO}_{3}$

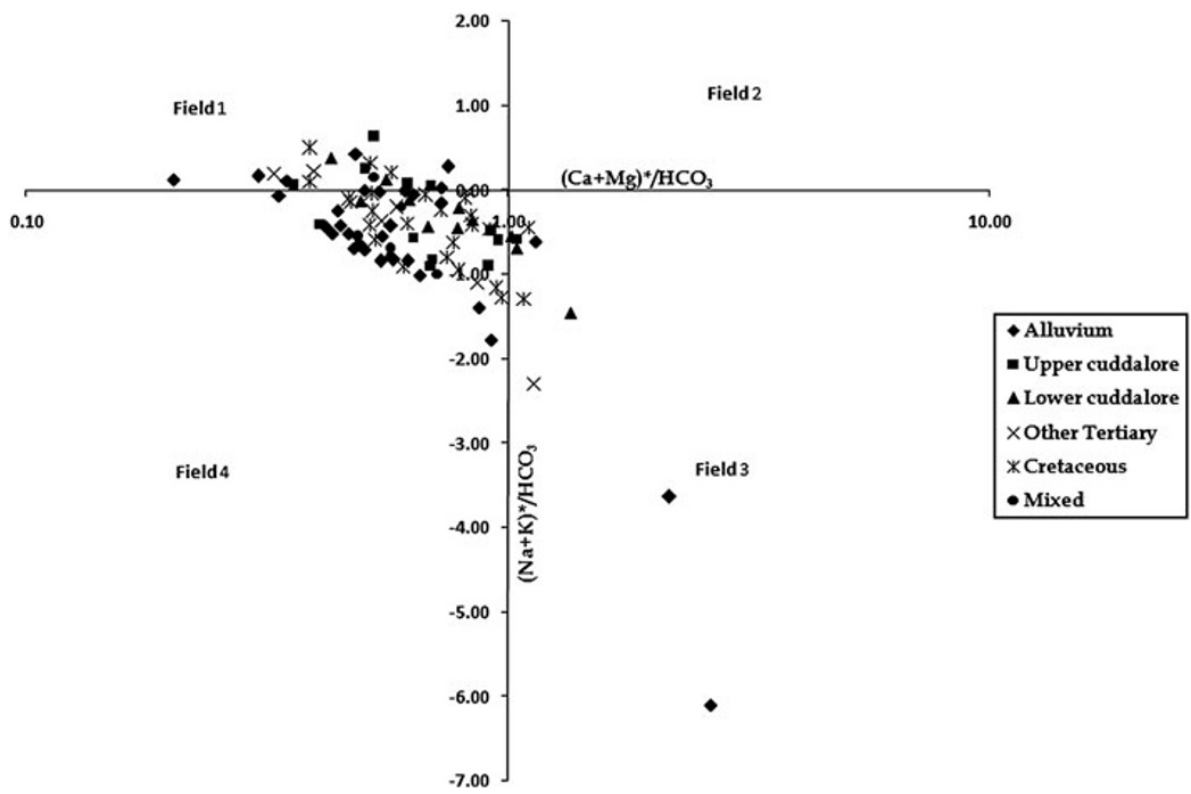

$\left(\mathrm{Na}^{+}+\mathrm{K}\right)^{*}$. This shows that the field has dominance of excess $\left(\mathrm{Ca}^{2+}+\mathrm{Mg}^{2+}\right) *$ and $\left(\mathrm{Na}^{+}+\mathrm{K}\right)^{*}$, with no significant indications of influencing anions due to contamination. Field 3 has the dominance of excess anion $\mathrm{Cl}^{-}$over $\mathrm{Na}+\mathrm{K}$ and higher $\left(\mathrm{Ca}^{2+}+\mathrm{Mg}^{2+}\right)^{*}$, which may be due to ion exchange with $\mathrm{Ca}-\mathrm{Mg}-\mathrm{Cl}$ water type. Field 4 represents the $\mathrm{Ca}-\mathrm{Mg}-$ $\mathrm{HCO}_{3}-\mathrm{Cl}$ water type. Most of the groundwater samples in the study area are in Field 4, representing $\mathrm{Ca}-\mathrm{Mg}-\mathrm{HCO}_{3}-\mathrm{Cl}$ water type, and few of them are represented in Field 1 (Fig. 6). This suggests that weathering of silicate minerals or saline intrusions are the significant contributors to the water chemistry of this region.

Ionic strength

Ionic strength is a measure of total concentration of ions, which emphasizes increased contribution of species with charges greater than one to solution non-ideality (Domenico and Schwartz 1998).

$I=0.5 \sum m_{1} z_{1}^{2}$

where $m_{1}$ is the atomic/molecular weight and $z_{1}$ is the valance of the respective ion. Ionic strength of freshwater is less than 0.005 (Hem 1959). In the study area, higher ionic strength was noted in alluvium and Tertiary formations, indicating lesser inflow of freshwater into the system. Low ionic strength was noted in Cretaceous formation indicating higher inflow of freshwater/recharge (Prasanna et al. 2006).

Partial pressure of carbon dioxide $\left(p \mathrm{CO}_{2}\right)$

The partial pressure of $\mathrm{CO}_{2}\left(p \mathrm{CO}_{2}\right)$ in rivers is commonly out of equilibrium with the atmosphere. The $\log p \mathrm{CO}_{2}$ for each sample is determined to study its relation to recharge. The atmospheric $\log p \mathrm{CO}_{2}$ value is around -3.75 (Raymahashay 1986). Water with high $p \mathrm{CO}_{2}$ of around -1.5 results due to deep circulation of groundwaters, with lesser atmospheric interaction or due to higher saturation of carbonates, resulting from the interaction with the host rock of the material through which it flows (Chidambaram et al. 2011).

In mixed water, $p \mathrm{CO}_{2}$ tends to decreases to the atmospheric value and this causes increase in saturation, suggesting that the mixing zone is an open system (Raymahashay 1986). The composition of freshwater is controlled by dissolution and precipitation processes and by degassing of $\mathrm{CO}_{2}$. The $\log p \mathrm{CO}_{2}$ values range from -2.5 to -1 . The samples from Tertiary, Lower and Upper Cuddalore Formations and few samples of alluvium show nearly the same value (Fig. 7). Lower values of $p \mathrm{CO}_{2}$ were noted in the alluvial and Cretaceous aquifers and also in few Lower Cuddalore sandstone samples, indicating recharge effect. Some samples from Cretaceous formation show higher $p \mathrm{CO}_{2}$ value, suggesting that the additional $\mathrm{CO}_{2}$ has been acquired from the soils during the process of infiltration towards the zone of saturation (Prasanna et al. 2006).

\section{Water quality}

\section{Domestic water quality}

The physicochemical properties related to the salinity of water can be appreciated by the measurements of the following parameters: chloride concentration, electric 
Fig. 7 The ratio between $\mathrm{pH}$ and $\log p \mathrm{CO}_{2}$

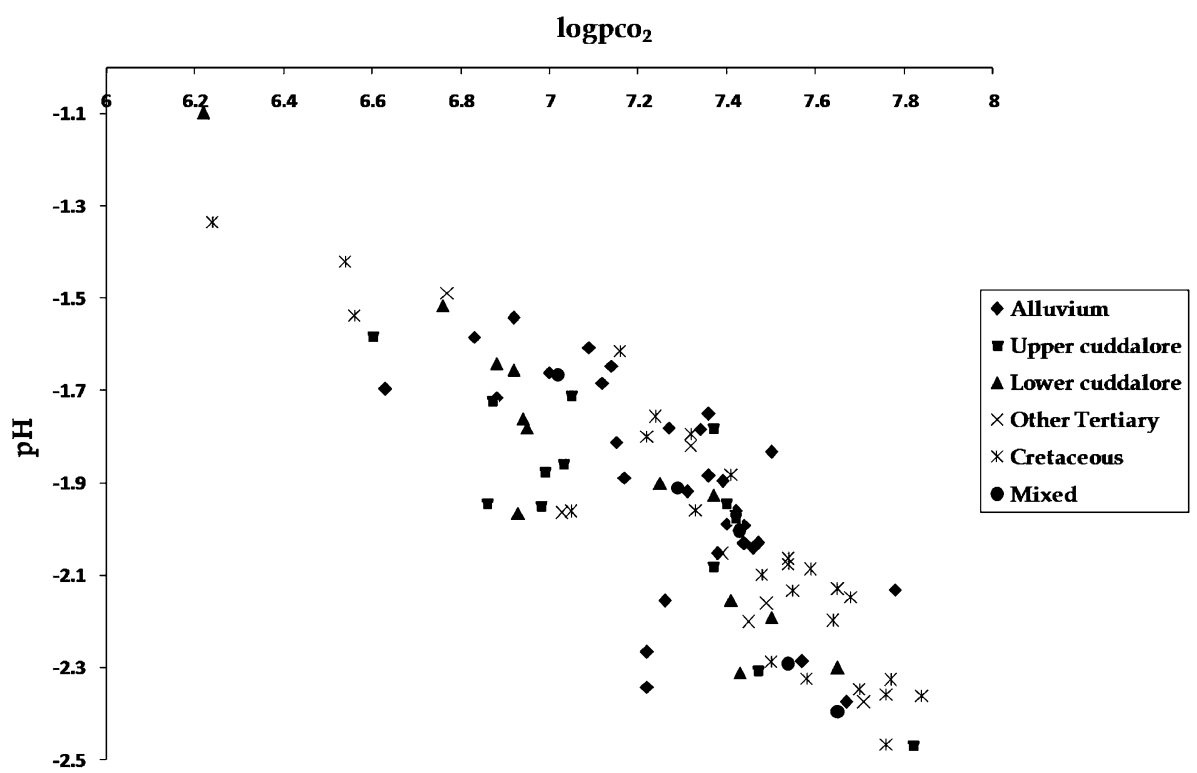

plotted using Richard (1954) classification. It was found that $90 \%$ of samples in alluvium formation fall under excellent categories, $7 \%$ fall in good class and the remaining $3 \%$ fall under the permissible category (Table 5). The samples from mixed and Lower Cuddalore Formations fall in excellent category; $92 \%$ of samples in Upper Cuddalore Formation are in excellent category and $8 \%$ are in good category. In Tertiary formation, $86 \%$ of samples fall in excellent category and $14 \%$ under good category. In Cretaceous, $96 \%$ of the samples fall under excellent category and 4 in good category.

\section{Sodium percentage $(\mathrm{Na} \%)$}

$\mathrm{Na}$ is an important cation, which in excess deteriorates the soil structure and reduces crop yield (Srinivasamoorthy et al. 2005). Na concentration is important in classifying water for irrigation purposes (Wilcox 1955). As much as $45 \%$ of samples in alluvial formation are in the doubtful range of about (60-80) of $\mathrm{Na} \%$, and $10 \%$ of samples are unsuitable ( $>80$ ) for irrigation purpose (Table 5). In Lower Cuddalore, $15 \%$ of the samples are in excellent and $69 \%$ of the samples under good category. In Upper Cuddalore,

Table 4 Typology of water according to their content of TDS (Desjardins 1988)

\begin{tabular}{|c|c|c|c|c|c|c|c|}
\hline \multirow[t]{2}{*}{ Water type } & \multirow{2}{*}{$\begin{array}{l}\text { Range } \\
\text { (ppm) }\end{array}$} & \multirow{2}{*}{$\begin{array}{l}\text { Alluvium } \\
(n=31)(\%)\end{array}$} & \multicolumn{3}{|l|}{ Tertiary } & \multirow{2}{*}{$\begin{array}{l}\text { Cretaceous } \\
(n=25)(\%)\end{array}$} & \multirow{2}{*}{$\begin{array}{l}\text { Mixed } \\
(n=5)(\%)\end{array}$} \\
\hline & & & $\begin{array}{l}\text { Upper Cuddalore } \\
(n=13)(\%)\end{array}$ & $\begin{array}{l}\text { Lower Cuddalore } \\
(n=13)(\%)\end{array}$ & $\begin{array}{l}\text { Other Tertiary } \\
(n=7)(\%)\end{array}$ & & \\
\hline Freshwater & $<500$ & 12.90 & 69.20 & 84.60 & 42.80 & 40 & 20 \\
\hline $\begin{array}{l}\text { Moderately fresh- } \\
\text { brackish water }\end{array}$ & $500-1,000$ & 58 & 23 & 15.30 & 42.80 & 44 & 60 \\
\hline $\begin{array}{l}\text { Slightly brackish } \\
\text { water }\end{array}$ & $1,000-5,000$ & 29 & 7.60 & - & 14.20 & 16 & 20 \\
\hline
\end{tabular}




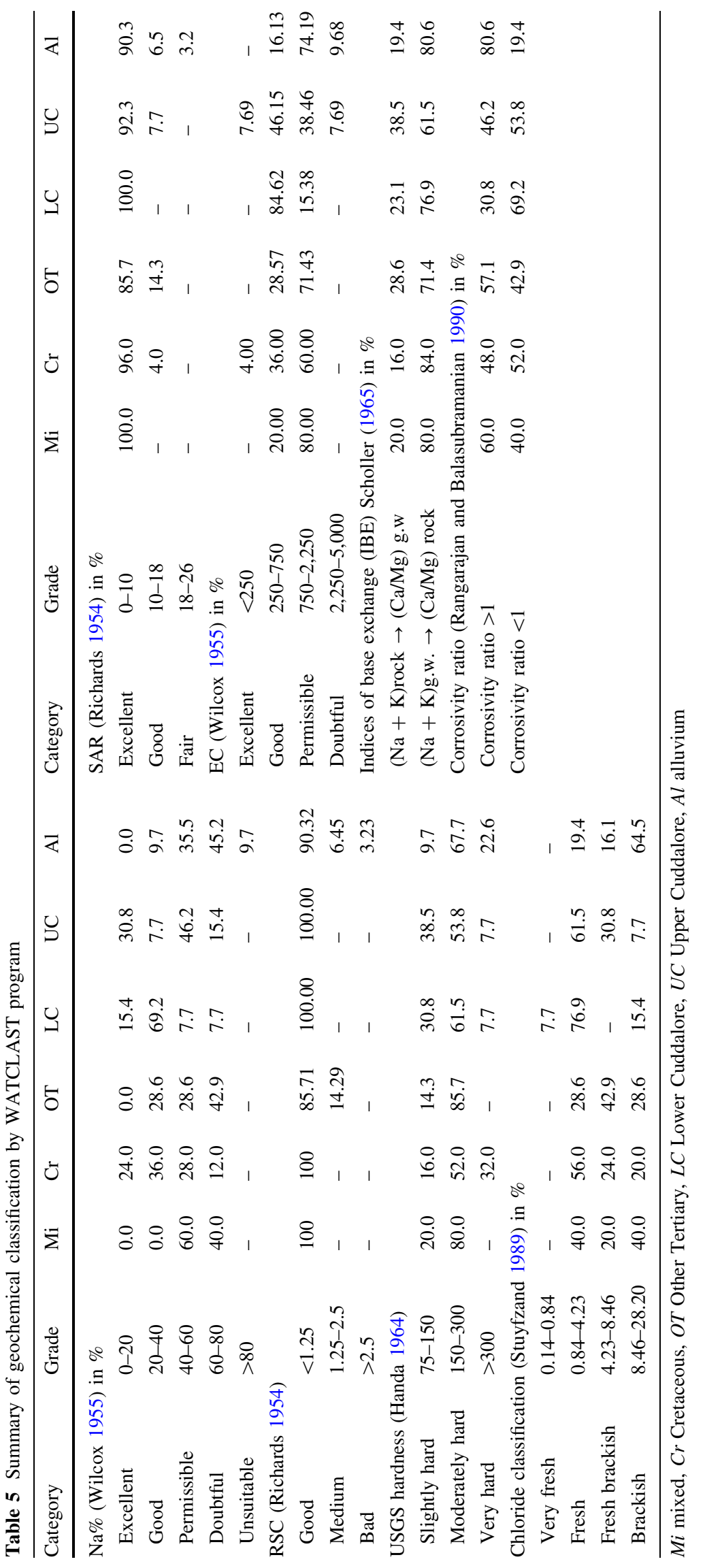


$31 \%$ of the samples are in excellent, $8 \%$ in good category, $46 \%$ in permissible and $15 \%$ in the doubtful range. In Other Tertiary formations, $43 \%$ of samples are in the doubtful range and $60 \%$ of the samples in the permissible range. In mixed formation, $60 \%$ of the samples fall under permissible range and $40 \%$ are grouped in the doubtful range. In Cretaceous, $24 \%$ of the samples are in excellent and $36 \%$ are under good category, while $12 \%$ of samples are in the doubtful category. Sodium percentage is calculated against major cations and expressed in terms of SAR. SAR values in all the major litho units range from excellent to good category and the majority of samples fall in the excellent category.

In Wilcox (1955) classification of electrical conductivity, $16 \%$ of samples in alluvium fall in good category, $74 \%$ are in the permissible range and a minor representation of $9.6 \%$ in the doubtful category (Table 5). About $46.2 \%$ of samples in Upper Cuddalore fall in the good category, $38.4 \%$ in permissible limit and only $7.6 \%$ in excellent category. Most of the samples fall in good to permissible range in Other Tertiary, Lower Cuddalore, Cretaceous and mixed formation.

\section{Hardness}

Hardness is defined as the sum of concentration of their ions expressed in $\mathrm{mg} / \mathrm{L}$ of $\mathrm{CaCO}_{3}$. Hardness increases from metallic ions dissolved in water. Hardness is used as an indicator of the rate of scale formation in hot water heaters in low-pressure boilers. USGS hardness (Handa 1964) shows four categories of hardness: soft, slightly hard, moderately hard and very hard. Scaling and deposition problems in air-conditioning plants are associated with the total hardness of water. Total hardness of more than $180 \mathrm{mg}$ $\mathrm{CaCO}_{3} / \mathrm{L}$ can be treated as very hard water and can lead to scaling problems in air-conditioning plants (Hem 1970).

The moderately hard water is represented in $68 \%$ of the samples and $22 \%$ of very hard category in alluvium formation (Table 5). In Upper Cuddalore, $39 \%$ of samples are slightly hard, $54 \%$ fall under moderately hard and $7 \%$ are in the very hard category. The same trend was followed in Lower Cuddalore. In Other Tertiary formations, $86 \%$ of samples are slightly hard and $14 \%$ in the moderately hard range. In Cretaceous, $16 \%$ of the samples are in the slightly hard category, $52 \%$ in the moderately hard and $32 \%$ in the very hard category. In mixed formation, $20 \%$ of samples fall under the slightly hard category and $80 \%$ in the moderately hard category.

Residual sodium carbonate

Water having excess of carbonate and bicarbonate cover the alkaline earth; mainly $\mathrm{Ca}$ and $\mathrm{Mg}$ in excess of the allowable limits affect agriculture unfavourably (Richards 1954).

$\mathrm{RSC}=\left(\mathrm{CO}_{3}+\mathrm{HCO}_{3}\right)-(\mathrm{Ca}+\mathrm{Mg})$

All values expressed in epm.

The tendency of alkaline earth influences the suitability of water for irrigation purposes. Water with $\mathrm{Ca}$ and $\mathrm{Mg}$ gets more precipitated and as a result $\mathrm{Na}$ in water gets increased in the form of sodium carbonate. The variation in RSC was drawn using (Richards 1954) good, medium and bad categories; $90 \%$ of the samples in alluvium fall in the good category, $6.4 \%$ in the medium category and $3.2 \%$ in the bad category (Table 5). Good category is found in all other formations except in Other Tertiary, where $86 \%$ are in good and $14 \%$ in medium category.

Index of base exchange (IBE)

Scholler (1965) proposed a measure called "index of base exchange" (IBE) to describe the geochemical reactions taking place in groundwater. There are substances which absorb and exchange their cations with cations present in groundwater. Those substances are called permutolites, e.g. clay minerals like kaolinite, illite, chlorite, halloysite, glauconite, zeolites and organic substances. Kaolinite, illite, chlorite and halloysite are the clay minerals in which ions are held at edges and their ionic exchange capacity is low. This case is reverse in montmorillonite and vermiculite; the exchange capacity is higher when the number of ions held on the surface is more. Chloro-alkaline indices, CAI1 and CAI2, are used to measure the extent of base exchange during rock-water interaction. Where there is an exchange of $\mathrm{Na}^{+}$and $\mathrm{K}^{+}$in groundwater with $\mathrm{Mg}^{2+}$ or $\mathrm{Ca}^{2+}$ in rock/alluvium, both the indices are positive and vice versa. All ionic concentration is expressed in epm. The indices to base exchange indicate that there is a significant exchange of $\mathrm{Na}+\mathrm{K}$ in groundwater into the $\mathrm{Ca}+\mathrm{Mg}$ in rock from the matrix, whereas the reverse is more prominent and the exchange of $\mathrm{Na}+\mathrm{K}$ in rock to the $\mathrm{Ca}+\mathrm{Mg}$ in groundwater is less notable (Chidambaram 2000). More than $60 \%$ of samples fall in $(\mathrm{Na}+\mathrm{K})$ groundwater $\rightarrow \mathrm{Mg} / \mathrm{Ca}$ rock and few of the samples are in $(\mathrm{Na}+\mathrm{K})$ rock $\rightarrow \mathrm{Mg} / \mathrm{Ca}$. The Styfzands classification of chloride shows that $19 \%$ of samples are in the fresh range, $16 \%$ are under the fresh-brackish range and $65 \%$ are brackish in nature in alluvium (Table 5). In Lower Cuddalore, $61 \%$ of samples are fresh in nature, $31 \%$ fresh-brackish and $8 \%$ brackish. In Other Tertiary, $28.6 \%$ of the samples are under fresh and $43 \%$ of the samples are under the freshbrackish categories, while $29 \%$ of the samples are brackish in nature. In Cretaceous, $56 \%$ of the samples are in the fresh category, $24 \%$ in the fresh-brackish range and $20 \%$ in brackish nature. In mixed formation, $40 \%$ of 
samples are under fresh category, $20 \%$ in fresh-brackish and $40 \%$ under brackish category.

\section{Corrosivity ratio}

Corrosivity ratio is $>1$ in most of the samples in all formations (Table 5). In alluvium, $19 \%$ of samples fall under corrosivity ratio $<1,54 \%$ in Upper Cuddalore, $70 \%$ in Lower Cuddalore, $43 \%$ in Other Tertiary, $52 \%$ in Cretaceous and $40 \%$ in mixed formation having the ratio $<1$.

Permeability index

Permeability index is an important factor, which influences quality of irrigation water in relation to soil for development in agriculture. Based on permeability index, (Table 6) Doneen (1948) classified the groundwater as Class I, Class II and Class III to find out the suitability of groundwater for irrigation purposes. The majority of samples in all the formations fall in Class I and Class II, indicating that the water is moderate to good for irrigation purposes with minor indication in poor irrigation quality.

\section{Correlation}

Correlation coefficient is commonly used to measure the relationship between two variables. It is simply a measure to exhibit how well one variable predicts the behaviour of the other. Correlation analysis was performed individually in all the formations (Table 7).

\section{Alluvium}

In alluvium, good correlation exists between $\mathrm{Cl}-\mathrm{Na}$, $\mathrm{HCO}_{3}-\mathrm{Ca}, \mathrm{HCO}_{3}-\mathrm{Na}, \mathrm{HCO}_{3}-\mathrm{Cl}, \mathrm{SO}_{4}-\mathrm{Ca}, \mathrm{Ca}-\mathrm{NO}_{3}, \mathrm{Mg}-$ $\mathrm{Na}, \mathrm{Mg}-\mathrm{Ca}, \mathrm{Mg}-\mathrm{Cl}$ and $\mathrm{Mg}-\mathrm{SO}_{4}$. Poor correlation exists between $\mathrm{SO}_{4}, \mathrm{PO}_{4}$ and $\mathrm{H}_{4} \mathrm{SiO}_{4}$ with all other ions. $\mathrm{Cl}$ shows good correlation with $\mathrm{Na}$ indicating leaching of secondary salts; a significant correlation of $\mathrm{HCO}_{3}$ with $\mathrm{Ca}, \mathrm{Na}$ and $\mathrm{Cl}$ indicates chemical weathering (Table 7). Poor positive correlation of $\mathrm{SO}_{4}, \mathrm{PO}_{4}$ and $\mathrm{H}_{4} \mathrm{SiO}_{4}$ shows the lesser possibility of anthropogenic influence into the system.
Tertiary Lower Cuddalore

Good correlation exhibits between $\mathrm{Na}-\mathrm{Ca}, \mathrm{Cl}-\mathrm{Ca}, \mathrm{Cl}-\mathrm{Na}$, $\mathrm{HCO}_{3}-\mathrm{Na}, \mathrm{Na}-\mathrm{SO}_{4}, \mathrm{NO}_{3}-\mathrm{Ca}, \mathrm{NO}_{3}-\mathrm{Na}, \mathrm{NO}_{3}-\mathrm{Cl}, \mathrm{NO}_{3}-$ $\mathrm{HCO}_{3}, \mathrm{SO}_{4}-\mathrm{Ca}, \mathrm{SO}_{4}-\mathrm{Cl}, \mathrm{SO}_{4}-\mathrm{HCO}_{3}$ and $\mathrm{SO}_{4}-\mathrm{NO}_{3}$, indicating the leaching of secondary salts along with anthropogenic impact. Poor correlation exists between $\mathrm{Mg}$ and $\mathrm{PO}_{4}$ with other ions indicating lesser influence of magnesium during this season. $\mathrm{SO}_{4}$ shows good positive correlation with $\mathrm{Na}$, indicating the leaching of marcasite present in this region (Sivalingam 2006). Good correlation between $\mathrm{HCO}_{3}, \mathrm{Na}$ and $\mathrm{H}_{4} \mathrm{SiO}_{4}$ indicates albite weathering. $\mathrm{H}_{4} \mathrm{SiO}_{4}$ is well correlated with $\mathrm{Ca}$ and $\mathrm{Mg}$, indicating intensive weathering reaction that enhances $\mathrm{H}_{4} \mathrm{SiO}_{4} \mathrm{Cl}$ shows good correlation with $\mathrm{Ca}$ and $\mathrm{Na}$, indicating leaching of salts.

\section{Tertiary Upper Cuddalore}

Good correlation exists between $\mathrm{Na}-\mathrm{Ca}, \mathrm{Na}-\mathrm{Mg}, \mathrm{K}-\mathrm{Ca}$, $\mathrm{K}-\mathrm{Mg}, \mathrm{K}-\mathrm{Na}, \mathrm{Cl}-\mathrm{Ca}, \mathrm{Cl}-\mathrm{Mg}, \mathrm{Cl}-\mathrm{Na}, \mathrm{Cl}-\mathrm{K}, \mathrm{SO}_{4}-\mathrm{Ca} \mathrm{SO}_{4}-$ $\mathrm{Mg}, \mathrm{SO}_{4}-\mathrm{Na}, \mathrm{SO}_{4}-\mathrm{K}, \mathrm{SO}_{4}-\mathrm{Cl}, \mathrm{NO}_{3}-\mathrm{PO}_{4}$ and $\mathrm{SO}_{4}-\mathrm{Mg}$, indicating the leaching of secondary salts along with anthropogenic activities. $\mathrm{Cl}$ shows good correlation with $\mathrm{Ca}$, $\mathrm{Mg}, \mathrm{Na}$ and $\mathrm{K}$, indicating secondary leaching of salts. $\mathrm{HCO}_{3}$ is well correlated with $\mathrm{Na}$, indicating weathering of sodic feldspar from the source rock. Good to poor positive correlation of $\mathrm{HCO}_{3}, \mathrm{Na}, \mathrm{K}$ and $\mathrm{H}_{4} \mathrm{SiO}_{4}$ indicates albite weathering from the source rock. $\mathrm{Cl}$ shows good correlation with $\mathrm{Ca}, \mathrm{Na}$ and $\mathrm{K}$, indicating secondary leaching of salts.

\section{Other Tertiary formations}

Good correlation exists between $\mathrm{Cl}-\mathrm{Na}, \mathrm{NO}_{3}-\mathrm{Na}, \mathrm{NO}_{3}-\mathrm{Cl}$, $\mathrm{SO}_{4}-\mathrm{Cl}$ and $\mathrm{SO}_{4}-\mathrm{NO}_{3}$, indicating the leaching of secondary salts along with anthropogenic impact. Poor correlation exists between $\mathrm{Mg}$ and $\mathrm{PO}_{4}$ with other ions indicating the influence of agriculture input into the aquifers. $\mathrm{Cl}$ shows good correlation with $\mathrm{Ca}$ and $\mathrm{Na}$, indicating leaching of salts.

Cretaceous and mixed

Good correlation exists between $\mathrm{Cl}-\mathrm{Na}, \mathrm{HCO}_{3}-\mathrm{Ca}, \mathrm{HCO}_{3}-$ $\mathrm{Na}, \mathrm{HCO}_{3}-\mathrm{Cl}$ and $\mathrm{SO}_{4}-\mathrm{Ca}$ indicating the leaching of

Table 6 The permeability index of the samples

\begin{tabular}{|c|c|c|c|c|c|c|}
\hline \multirow{2}{*}{$\begin{array}{l}\text { Permeability } \\
\text { index range }\end{array}$} & \multirow{2}{*}{$\begin{array}{l}\text { Alluvium } \\
(n=31)(\%)\end{array}$} & \multicolumn{3}{|l|}{ Tertiary } & \multirow{2}{*}{$\begin{array}{l}\text { Cretaceous } \\
(n=25)(\%)\end{array}$} & \multirow{2}{*}{$\begin{array}{l}\text { Mixed } \\
(n=5)(\%)\end{array}$} \\
\hline & & $\begin{array}{l}\text { Upper Cuddalore } \\
(n=13)(\%)\end{array}$ & $\begin{array}{l}\text { Lower Cuddalore } \\
(n=13)(\%)\end{array}$ & $\begin{array}{l}\text { Other Tertiary } \\
(n=7)(\%)\end{array}$ & & \\
\hline $40-60$ & 6.45 & 23.08 & 38.46 & 28.57 & 44 & 0 \\
\hline $60-80$ & 48.39 & 53.85 & 53.85 & 28.57 & 44 & 80 \\
\hline 80-100 & 45.16 & 23.08 & 7.69 & 42.86 & 12 & 20 \\
\hline
\end{tabular}


Table 7 Correlation analysis for groundwater samples

\begin{tabular}{|c|c|c|c|c|c|c|c|c|c|c|c|c|}
\hline & $\mathrm{Ca}$ & $\mathrm{Mg}$ & $\mathrm{Na}$ & $\mathrm{K}$ & $\mathrm{Cl}$ & $\mathrm{HCO}_{3}$ & $\mathrm{NO}_{3}$ & $\mathrm{PO}_{4}$ & $\mathrm{SO}_{4}$ & $\mathrm{SiO}_{2}$ & $\mathrm{pH}$ & $\mathrm{EC}$ \\
\hline \multicolumn{13}{|l|}{$\mathrm{Al}$} \\
\hline $\mathrm{Ca}$ & 1.00 & & & & & & & & & & & \\
\hline $\mathrm{Mg}$ & -0.05 & 1.00 & & & & & & & & & & \\
\hline $\mathrm{Na}$ & 0.18 & -0.12 & 1.00 & & & & & & & & & \\
\hline $\mathrm{K}$ & 0.41 & 0.24 & 0.12 & 1.00 & & & & & & & & \\
\hline $\mathrm{Cl}$ & 0.33 & 0.06 & 0.92 & 0.19 & 1.00 & & & & & & & \\
\hline $\mathrm{HCO}_{3}$ & 0.30 & -0.12 & 0.37 & 0.36 & 0.29 & 1.00 & & & & & & \\
\hline $\mathrm{NO}_{3}$ & -0.05 & -0.17 & 0.08 & -0.13 & 0.04 & 0.34 & 1.00 & & & & & \\
\hline $\mathrm{PO}_{4}$ & 0.24 & 0.24 & -0.06 & 0.43 & -0.01 & 0.32 & 0.32 & 1.00 & & & & \\
\hline $\mathrm{SO}_{4}$ & 0.50 & 0.14 & 0.16 & 0.43 & 0.17 & 0.07 & -0.03 & 0.39 & 1.00 & & & \\
\hline $\mathrm{SiO}_{2}$ & 0.22 & -0.10 & -0.04 & -0.19 & -0.01 & 0.07 & 0.26 & -0.30 & -0.03 & 1.00 & & \\
\hline $\mathrm{pH}$ & -0.11 & 0.12 & 0.35 & 0.24 & 0.26 & 0.51 & 0.13 & 0.11 & 0.13 & 0.04 & 1.00 & \\
\hline $\mathrm{EC}$ & 0.62 & 0.09 & 0.75 & 0.53 & 0.81 & 0.50 & 0.06 & 0.29 & 0.45 & 0.07 & 0.41 & 1.00 \\
\hline \multicolumn{13}{|l|}{ LC } \\
\hline $\mathrm{Ca}$ & 1.00 & & & & & & & & & & & \\
\hline $\mathrm{Mg}$ & 0.36 & 1.00 & & & & & & & & & & \\
\hline $\mathrm{Na}$ & 0.78 & 0.10 & 1.00 & & & & & & & & & \\
\hline $\mathrm{K}$ & -0.03 & 0.31 & -0.05 & 1.00 & & & & & & & & \\
\hline $\mathrm{Cl}$ & 0.93 & 0.26 & 0.89 & -0.02 & 1.00 & & & & & & & \\
\hline $\mathrm{HCO}_{3}$ & 0.45 & 0.34 & 0.73 & 0.05 & 0.49 & 1.00 & & & & & & \\
\hline $\mathrm{NO}_{3}$ & 0.78 & 0.30 & 0.90 & -0.08 & 0.78 & 0.77 & 1.00 & . & & & & \\
\hline $\mathrm{PO}_{4}$ & 0.00 & 0.00 & 0.00 & 0.00 & 0.00 & 0.00 & 0.00 & 1.00 & & & & \\
\hline $\mathrm{SO}_{4}$ & 0.65 & 0.12 & 0.86 & -0.03 & 0.79 & 0.71 & 0.77 & 0.00 & 1.00 & & & \\
\hline $\mathrm{SiO}_{2}$ & 0.75 & 0.04 & 0.98 & -0.12 & 0.86 & 0.72 & 0.86 & 0.00 & 0.82 & 1.00 & & \\
\hline $\mathrm{pH}$ & 0.51 & 0.55 & 0.51 & -0.09 & 0.49 & 0.57 & 0.65 & 0.00 & 0.50 & 0.40 & 1.00 & \\
\hline $\mathrm{EC}$ & 0.75 & 0.25 & 0.95 & -0.02 & 0.80 & 0.85 & 0.94 & 0.00 & 0.79 & 0.94 & 0.59 & 1.00 \\
\hline \multicolumn{13}{|l|}{$\mathrm{Cr}$} \\
\hline $\mathrm{Ca}$ & 1.00 & & & & & & & & & & & \\
\hline $\mathrm{Mg}$ & 0.31 & 1.00 & & & & & & & & & & \\
\hline $\mathrm{Na}$ & 0.36 & 0.14 & 1.00 & & & & & & & & & \\
\hline $\mathrm{K}$ & 0.37 & 0.03 & -0.01 & 1.00 & & & & & & & & \\
\hline $\mathrm{Cl}$ & 0.45 & 0.30 & 0.95 & 0.06 & 1.00 & & & & & & & \\
\hline $\mathrm{HCO}_{3}$ & 0.54 & 0.47 & 0.55 & 0.02 & 0.53 & 1.00 & & & & & & \\
\hline $\mathrm{NO}_{3}$ & 0.30 & 0.44 & 0.26 & -0.07 & 0.30 & 0.43 & 1.00 & & & & & \\
\hline $\mathrm{PO}_{4}$ & 0.39 & 0.29 & 0.16 & 0.36 & 0.31 & 0.14 & -0.25 & 1.00 & & & & \\
\hline $\mathrm{SO}_{4}$ & 0.74 & 0.18 & 0.23 & 0.40 & 0.26 & 0.30 & 0.28 & 0.08 & 1.00 & & & \\
\hline $\mathrm{SiO}_{2}$ & 0.29 & 0.00 & 0.48 & -0.04 & 0.44 & 0.37 & 0.53 & -0.31 & 0.27 & 1.00 & & \\
\hline $\mathrm{pH}$ & 0.41 & 0.06 & 0.04 & -0.08 & -0.03 & 0.59 & 0.09 & 0.00 & 0.24 & 0.27 & 1.00 & \\
\hline \multirow[t]{2}{*}{$\mathrm{EC}$} & 0.58 & 0.45 & 0.84 & 0.01 & 0.86 & 0.65 & 0.52 & 0.18 & 0.46 & 0.51 & 0.14 & 1.00 \\
\hline & $\mathrm{Ca}$ & $\mathrm{Mg}$ & $\mathrm{Na}$ & $\mathrm{K}$ & $\mathrm{Cl}$ & $\mathrm{HCO}_{3}$ & $\mathrm{NO}_{3}$ & $\mathrm{PO}_{4}$ & $\mathrm{SO}_{4}$ & $\mathrm{SiO}_{2}$ & $\mathrm{pH}$ & EC \\
\hline \multicolumn{13}{|l|}{$\mathrm{UC}$} \\
\hline $\mathrm{Ca}$ & 1.00 & & & & & & & & & & & \\
\hline $\mathrm{Mg}$ & 0.13 & 1.00 & & & & & & & & & & \\
\hline $\mathrm{Na}$ & 0.69 & 0.59 & 1.00 & & & & & & & & & \\
\hline $\mathrm{K}$ & 0.74 & 0.52 & 0.71 & 1.00 & & & & & & & & \\
\hline $\mathrm{Cl}$ & 0.78 & 0.53 & 0.97 & 0.80 & 1.00 & & & & & & & \\
\hline $\mathrm{HCO}_{3}$ & 0.77 & 0.36 & 0.85 & 0.49 & 0.84 & 1.00 & & & & & & \\
\hline $\mathrm{NO}_{3}$ & 0.01 & -0.18 & -0.16 & -0.08 & -0.14 & -0.01 & 1.00 & & & & & \\
\hline
\end{tabular}


Table 7 continued

\begin{tabular}{|c|c|c|c|c|c|c|c|c|c|c|c|c|}
\hline & $\mathrm{Ca}$ & $\mathrm{Mg}$ & $\mathrm{Na}$ & $\mathrm{K}$ & $\mathrm{Cl}$ & $\mathrm{HCO}_{3}$ & $\mathrm{NO}_{3}$ & $\mathrm{PO}_{4}$ & $\mathrm{SO}_{4}$ & $\mathrm{SiO}_{2}$ & $\mathrm{pH}$ & EC \\
\hline $\mathrm{PO}_{4}$ & 0.27 & 0.33 & 0.55 & 0.28 & 0.47 & 0.35 & -0.36 & 1.00 & & & & \\
\hline $\mathrm{SO}_{4}$ & 0.75 & 0.55 & 0.64 & 0.78 & 0.70 & 0.59 & -0.18 & 0.14 & 1.00 & & & \\
\hline $\mathrm{SiO}_{2}$ & 0.03 & -0.27 & 0.06 & -0.33 & 0.05 & 0.40 & 0.36 & -0.15 & -0.31 & 1.00 & & \\
\hline $\mathrm{pH}$ & 0.26 & 0.07 & 0.34 & -0.18 & 0.24 & 0.60 & 0.01 & 0.34 & 0.22 & 0.32 & 1.00 & \\
\hline $\mathrm{EC}$ & 0.80 & 0.55 & 0.97 & 0.78 & 0.98 & 0.86 & -0.21 & 0.55 & 0.73 & -0.03 & 0.34 & 1.00 \\
\hline \multicolumn{13}{|l|}{ OT } \\
\hline $\mathrm{Ca}$ & 1.00 & & & & & & & & & & & \\
\hline $\mathrm{Mg}$ & -0.16 & 1.00 & & & & & & & & & & \\
\hline $\mathrm{Na}$ & 0.32 & -0.02 & 1.00 & & & & & & & & & \\
\hline $\mathrm{K}$ & 0.10 & 0.05 & -0.68 & 1.00 & & & & & & & & \\
\hline $\mathrm{Cl}$ & 0.41 & 0.24 & 0.93 & -0.69 & 1.00 & & & & & & & \\
\hline $\mathrm{HCO}_{3}$ & 0.03 & -0.66 & -0.08 & 0.31 & -0.36 & 1.00 & & & & & & \\
\hline $\mathrm{NO}_{3}$ & 0.29 & -0.41 & 0.76 & -0.81 & 0.67 & 0.17 & 1.00 & & & & & \\
\hline $\mathrm{PO}_{4}$ & -0.28 & 0.39 & -0.38 & 0.76 & -0.43 & 0.08 & -0.83 & 1.00 & & & & \\
\hline $\mathrm{SO}_{4}$ & 0.07 & -0.09 & 0.87 & -0.81 & 0.81 & -0.05 & 0.80 & -0.54 & 1.00 & & & \\
\hline $\mathrm{SiO}_{2}$ & -0.03 & -0.29 & 0.81 & -0.83 & 0.65 & -0.04 & 0.81 & -0.53 & 0.73 & 1.00 & & \\
\hline $\mathrm{pH}$ & -0.58 & -0.04 & 0.18 & 0.07 & -0.10 & 0.31 & -0.14 & 0.57 & 0.08 & 0.30 & 1.00 & \\
\hline EC & 0.30 & 0.17 & 0.90 & -0.71 & 0.91 & -0.10 & 0.78 & -0.46 & 0.79 & 0.71 & 0.02 & 1.00 \\
\hline \multicolumn{13}{|l|}{ Mi } \\
\hline $\mathrm{Ca}$ & 1.00 & & & & & & & & & & & \\
\hline $\mathrm{Mg}$ & -0.11 & 1.00 & & & & & & & & & & \\
\hline $\mathrm{Na}$ & 0.38 & 0.41 & 1.00 & & & & & & & & & \\
\hline $\mathrm{K}$ & 0.30 & 0.89 & 0.53 & 1.00 & & & & & & & & \\
\hline $\mathrm{Cl}$ & 0.55 & 0.42 & 0.95 & 0.57 & 1.00 & & & & & & & \\
\hline $\mathrm{HCO}_{3}$ & 0.59 & 0.46 & 0.83 & 0.75 & 0.79 & 1.00 & & & & & & \\
\hline $\mathrm{NO}_{3}$ & 0.45 & 0.72 & 0.22 & 0.80 & 0.44 & 0.40 & 1.00 & & & & & \\
\hline $\mathrm{PO}_{4}$ & 0.00 & 0.00 & 0.00 & 0.00 & 0.00 & 0.00 & 0.00 & 1.00 & & & & \\
\hline $\mathrm{SO}_{4}$ & 0.44 & 0.04 & 0.93 & 0.20 & 0.87 & 0.69 & -0.06 & 0.00 & 1.00 & & & \\
\hline $\mathrm{SiO}_{2}$ & -0.37 & 0.70 & 0.52 & 0.40 & 0.51 & 0.13 & 0.30 & 0.00 & 0.31 & 1.00 & & \\
\hline $\mathrm{pH}$ & -0.67 & 0.45 & -0.08 & 0.01 & -0.04 & -0.46 & 0.15 & 0.00 & -0.23 & 0.80 & 1.00 & \\
\hline $\mathrm{EC}$ & 0.28 & 0.86 & 0.77 & 0.94 & 0.78 & 0.82 & 0.68 & 0.00 & 0.49 & 0.59 & 0.09 & 1.00 \\
\hline
\end{tabular}

Al alluvium, UC Upper Cuddalore, $L C$ Lower Cuddalore, OT Other Tertiary, Cr Cretaceous, $M i$ mixed

secondary salts. Poor correlation exists between $\mathrm{Na}$ with other ions. The same trend was found in mixed formations.

\section{Conclusions}

The cation dominance is in the following order: $\mathrm{Na}^{+}>\mathrm{Ca}^{2+}>\mathrm{Mg}^{2+}>\mathrm{K}^{+}$and that of anions is $\mathrm{Cl}^{-}>\mathrm{HCO}_{3}{ }^{-}>\mathrm{SO}_{4}{ }^{2-}$. The study area forms a part of the coastal aquifer, and the higher EC extends from the southeastern part influenced by salt water intrusion. Higher $\mathrm{EC}$ is also observed in the central and western parts due to the leaching of ions. Most of the groundwater samples range from soft to moderately hard category. The Styfzands classification shows that all the samples fall in fresh to fresh-brackish category in all the aquifers. The Piper diagram shows that $\mathrm{Na}-\mathrm{Cl}$ is the dominant facies in all the aquifers with few representations of $\mathrm{Ca}-\mathrm{HCO}_{3}$ showing the recharge. Chadda's plot shows that saltwater intrusion and ion exchange are more common in alluvium, which has more representations of saltwater contaminated samples. The ionic strength for few of the samples is almost equivalent to freshwater. In general, the dilution effect is evident from the low ionic strength. Lower values of $p \mathrm{CO}_{2}$ were noted in the alluvial and Cretaceous aquifers and also in few Lower Cuddalore sandstone samples, indicating recharge effect. TDS is higher and exceeds the standard limits for drinking water in all the aquifers except in Upper Cuddalore. Few groundwater samples of the study area are unsuitable for domestic and drinking purposes. 
Open Access This article is distributed under the terms of the Creative Commons Attribution License which permits any use, distribution, and reproduction in any medium, provided the original author(s) and the source are credited.

\section{References}

Agarwal V, Jagetia MM (1997) Hydrogeochemical assessment of groundwater quality in Udaipur City, Rajasthan, India. In: Proceedings of national conference on "Dimensions of Environmental stress in India', Department of Geology, MS University, Baroda, pp 151-154

APHA (1998) Standard methods for the examination of water and wastewater, 19th edn. APHA, Washington, DC

Appelo CA, Postma D (1999) Geochemistry, groundwater and pollution. Balkema, Rotterdam

Back W (1960) Origin of hydrochemical facies of groundwater in the Atlantic Coastal plain. In: 21st international geological congress, Copenhagen 1960, Rept pt. 1, pp 87-95

CGWB (1993) Ground water resources and development prospects in Pondicherry region, Union Territory of Pondicherry

Chadha DK (1999) A proposed new diagram for geochemical classification of natural waters and interpretation of chemical data. Hydrogeol J 7(5):431-439

Chidambaram S (2000) Hydrogeochemical studies of groundwater in Periyar District, Tamilnadu, India. Ph.D. Thesis, Annamalai University

Chidambaram S, Prasanna MV, Karmegam U, Singaraja C, Pethaperumal S, Manivannan R, Anandhan P, Tirumalesh (2011) Significance of $p \mathrm{CO}_{2}$ values in determining carbonate chemistry in groundwater of Pondicherry region, India. Front Earth Sci 5(2):197-206

Dasgupta AM, Purohit KM (2001) Status of surface and groundwater quality of Mandiakadar-part II: agricultural utilities. Pollut Res 20(2):219-225

Desjardins R (1988) Le traitement des eaux. Edition II revue. Edition de l'Ecole Polytechnique de Montréal, Montréal

Domenico PA, Schwartz W (1998) Physical and chemical hydrogeology, 2nd edn. Wiley, New York, p 506

Doneen LD (1948) The quality of irrigation water, vol 4. California Agriculture Dept, pp 6-14.

Drever JI (1988) The geochemistry of natural waters, 2nd edn. Prentice-Hall, New York

Durvey VS, Sharma LL, Saini VP, Sharma BK (1997) Handbook on the methodology of water quality assessment. Rajasthan Agricultural University, India

Freeze AR, Cherry JA (1979) Groundwater. Prentice-Hall Inc, Englewood cliffs, p 604

Ghabayen MS, McKee Mac, Kemblowski Mariush (2006) Ionic and isotopic ratios for identification of salinity sources and missing data in the Gaza aquifer. J Hydrol 318:360-373

Handa BK (1964) Modified classification procedure for rating irrigation waters. Soil Sci 98(2):264-269

Hardie LA, Eugster HP (1978) The evolution of closed-basin brines. Min Soc Am Spec Publ 3:273-290

Hem JD (1959) Geochemistry of water calculation and use of ion activity. USGS water supply, $1935 \mathrm{C}$

Hem JD (1970) Study and interpretation of the chemical characteristics of natural water, 2nd edn. USGS Water Supply, 1473, p 363

Hem JD (1991) Study and interpretation of the chemical characteristics of natural waters, 3rd edn, Book 2254. Scientific Publishers, Jodhpur

Holden WS (1971) Water treatment and examination. Churchill, London
Hussain I, Hussain J, Dhinsa SS (2005) Groundwater quality variation in Bhilwara District, Rajasthan. Pollut Res 24(3):723-725

ISI (1983) Indian standard specification for drinking water. IS: 10500. Indian Standard Institute, India

Jankowski J, Jacobson G (1989) Hydrochemical evolution of regional groundwaters to playa brines in Central Australia. J Hydrol 108: 123-173

Karanth KR (1997) Groundwater assessment, development and management. Tata McGraw-Hill, New Delhi

Karmegam U, Chidambaram S, Sasidhar P, Manivannan R, Manikandan S, Anandhan P (2010) Geochemical characterization of groundwaters of shallow coastal aquifer in and around Kalpakkam, South India. Res J Environ Earth Sci 2(4):170177

Kelly WE (1976) Geoelectric sounding for delineating groundwater contamination. Ground Water 14(1):6-11

Khurshid SH, Hasan N, Zaheeruddin (2002) Water quality status and environmental hazards in parts of Yamuna-Karwan sub-basin of Aligarh-Mathura District, Uttar Pradesh, India. J Appl Hydrol 14(4):30-37

Krumbein WC, Sloss LL (1963) Stratigraphy and sedimentation, 2nd edn. Freeman, San Francisco

Kumar M, Ramanathan AL, Rao MS, Kumar B (2006) Identification and evaluation of hydrogeochemical process in the groundwater environment of Delhi, India. Environ Geol 50:1025-1039

Majumdar D, Gupta N (2000) Nitrate pollution of groundwater and associated human health disorders, India. J Environ Health 42(1):28-39

Metcafe, Eddy (2000) Integrated aquifer management plan: final report. Gaza Coastal Aquifer Management Program, USAID Contract No. 294-C-00-99-00038-00

Niranjan Babu P, Subba Rao N, Chandra Rao P, Prakesh Rao J (1997) Groundwater quality and its importance in the land developmental programmes, India. J Geol 69(4):305-312

Pethaperumal S (2010) Study on groundwater chemistry in the Pondicherry region. Ph.D. thesis, Annamalai University, India

Piper AM (1953) A graphic procedure I the geo-chemical interpretation of water analysis, USGS Groundwater Note no, 12

Prasanna MV, Chidambaram S, Srinivasamoorthy K, Anandhan P, John Peter A (2006) A study on hydrogeochemisty along the groundwater flow path is different litho units in Gadilam river basin, Tamilnadu (India). J Ultra Chem 2:2157-17210

Prasanna MV, Chidambaram S, Shahul Hameed A, Srinivasamoorthy K (2010) Study of evaluation of groundwater in Gadilam basin using hydrogeochemical and isotope data. Environ Monit Assess 168:63-90

Prasanna MV, Chidambaram S, Gireesh TV, Jabir Ali TV (2011) A study on hydrochemical characteristics of surface and subsurface water in and around Perumal Lake, Cuddalore District, Tamil Nadu, South India. Environ Earth Sci 64(5):14191431

Pulle JS, Khan AM, Ambore NE, Kadam DD, Pawar SK (2005) Assessment of groundwater quality of Nanded City. Pollut Res 24(3):657-660

Rangarajan R, Balasubramanian A (1990) Corrosion and scale formation characteristic of ground water in and around Nangavalli, Salem district, Tamilnadu. J Appl Hydrol 2:15-22

Raymahashay BC (1986) Geochemistry of bicarbonate in river water. J Geol Soc India 27:114-118

Richards LA (1954) Diagnosis and improvement of saline and alkali soils agriculture handbook 60. Department of Agricultural, Washington, DC, p 160

Scholler H (1965) Hydrodynamic Dam Lekar Collogue Doboronik 1, pp 3-20

Shipovalov GV (1984) Altitudinal hydrochemical zonations of groundwaters. Water Resour:261-265 
Sivalingam C (2006) Geochemistry of marcasite associated of Neyveli area, Tamil Nadu, South India. Ph.D., Published thesis, Annamalai University

Srinivasamoorthy K, Chidambaram S, Anandhan P, Vasudevan S (2005) Application of statistical analysis of the hydrogeochemical study of groundwater in hard rock terrain, Salem District, Tamilnadu. J Geochem 20:181-190

Stumm W, Morgan JJ (1996) Aquatic chemistry. Wiley Interscience, New York, pp 349-424

Stuyfzand PJ (1989) Non point sources of trace elements in potable groundwater in the Netherlands. In: Proceedings 18th TWSA water workings. Testing and Research Institute, KIWA

Stuyfzand PJ (1992) Behaviour of major and trace constituents in fresh and salt intrusion waters, in the western Netherlands. In: Custodio E (ed) Study and modelling of salt water intrusion into aquifers. In: Proceedings of the 12th salt water intrusion meeting, Barcelona. CIHS-CIMNE, Barcelona, pp 143-160

Stuyfzand PJ (1993) Hydrochemistry and hydrology of the coastal dune area of the Western Netherlands. Ph.D. Free University of Amsterdam. Kiwa Ltd, Research and Consultancy, Nieuwegein. IBSN 90-74741-01-0

Stuyfzand PJ (1999) Patterns in groundwater chemistry resulting from groundwater flow. Hydrol J 7:15-27

Subba Rao N (2006) Seasonal variation of groundwater quality in a part of Guntur district, Andhra Pradesh, India. Environ Geol 49:413-429

Subba Rao N, Srinivasa Rao G, Venkateswara Rao S, Madhusudhana Reddy P, John Devadas D (1999) Environmental control of groundwater quality in a tribal region of Andhra Pradesh, India. J Geol 71(4):299-304

Sujatha D, Reddy RB (2003) Quality characterization of groundwater in the south-eastern part of the Ranja Reddy District, Andhra Pradesh, India. Environ Geol 44(5):579-586

Sunitha V, Sudarsha V, Rajeswara Reddy B (2005) Hydrogeochemistry of groundwater, Gooty area, Anantapur District, Andhra Pradesh, India. Pollut Res 24(1):217-224
Thorne DW, Peterson HB (1954) Irrigated soils. Constable and Company, London

Tijani J (1994) Hydrochemical assessment of groundwater in Moro area, Kwara state, Nigeria. Environ Geol 24:194-202

Todd DK (1980) Groundwater hydrology. Wiley, New York

US Salinity Laboratory Staff (1954) Diagnosis and improvement of saline and alkali soils. US Department of Agricultural soils. US Department of Agricultural Hand Book 60, Washington

Vandenbohede A, Courtens C, William de Breuck L (2010) Freshsalt water distribution in the central Belgian coastal plain: an update. Geol Belg 11(3):163-172

Vengosh A, Ben-Zvi A (1994) Formation of a salt plume in the coastal plain aquifer of Israel: the Be'er Toviyya region. J Hydrol 160:21-52

Vengosh A, Rosenthal E (1994) Saline groundwater in Israel: its bearing on the water crisis in the country. J Hydrol 156:389-430

Vengosh A, Heumann KG, Juraski S, Kasher R (1994) Boron isotope application for tracing sources of contamination in groundwater. Environ Sci Technol 28(11):1968-1974

Vengosh A, Gill J, Davisson ML, Hudson GB (2002) A multiisotope $(\mathrm{B}, \mathrm{Sr}, \mathrm{O}, \mathrm{H}$, and $\mathrm{C})$ and age dating study of groundwater from Salinas Valley, California: hydrochemistry, dynamics, and contamination process. Water Resour Res 38(1):1-17

Versluys J (1931) Subterranean water conditions in the coastal regions of the Netherlands. Econ Geol 26:65-95

Walton WC (1970) Groundwater resources evaluation. McGraw Hill Book Co., New York

WHO (1984) Guidelines for drinking water quality. World Health Organization, Geneva

Wilcox LV (1955) Classification and use of irrigation water. US Department of Agriculture, Washington, p 969

Wilcox LV (1984) The quality of water for irrigation uses. US Department of Agricultural Technical Bulletin 1962, Washington

Zaporozec A (1972) Graphical interpretation of water quality data. Ground Water 10(2):32-43 